Prepared under the auspices of the U.S. Agency for International Development

\title{
Map and Database of Probable and Possible Quaternary Faults in Afghanistan
}

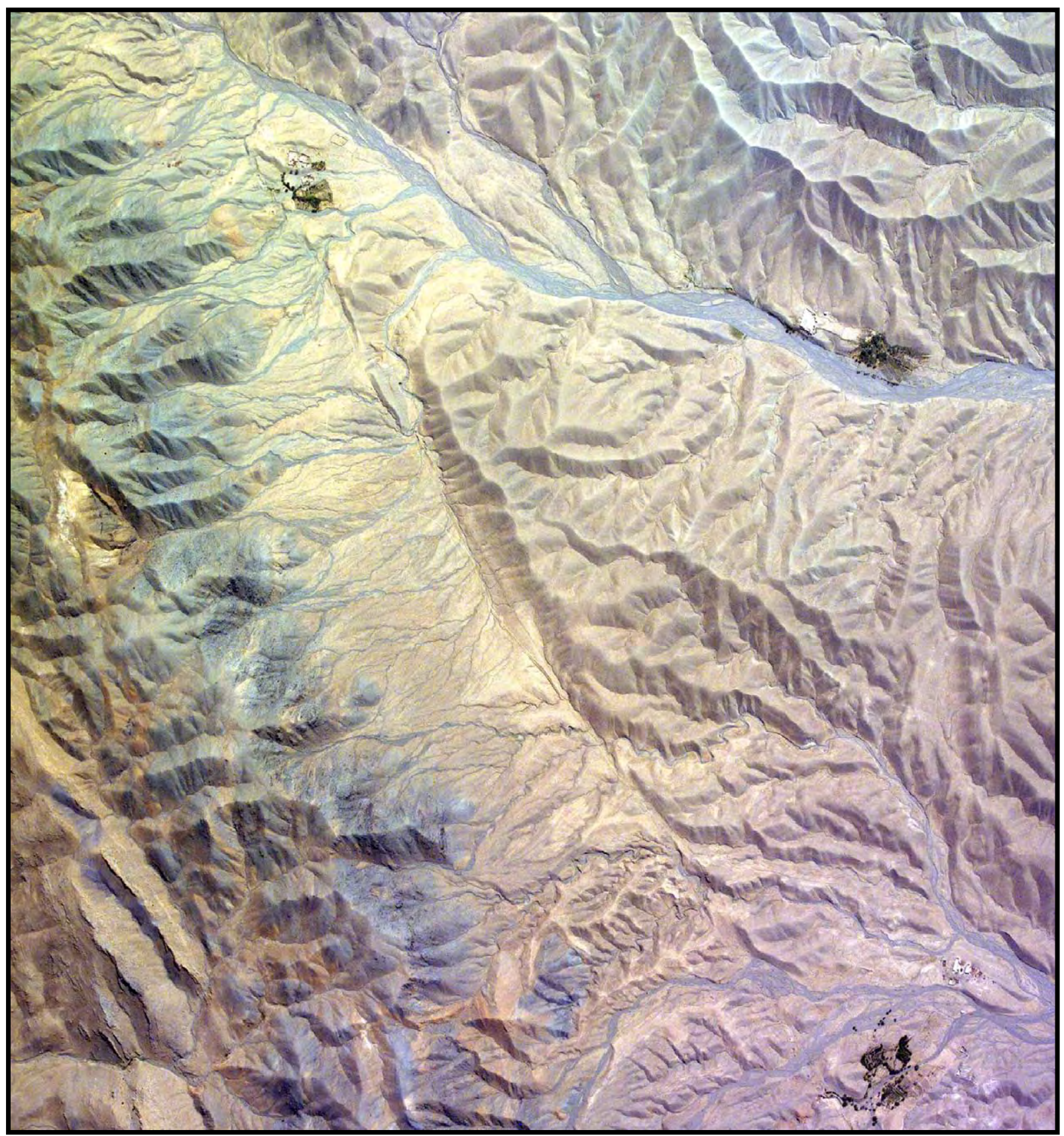

Open-File Report 2007-1103

USGS Afghanistan Project Product No. 150

U.S. Department of the Interior

U.S. Geological Survey 
Cover Photograph: Landsat image of the Chaman fault south of Kabul, Afghanistan. 


\section{Map and Database of Probable and Possible Quaternary Faults in Afghanistan}

By C.A. Ruleman, A.J. Crone, M.N. Machette, K.M. Haller and K.S. Rukstales

Open-File Report 2007-1103 


\title{
U.S. Department of the Interior DIRK KEMPTHORNE, Secretary
}

\author{
U.S. Geological Survey \\ Mark D. Myers, Director
}

U.S. Geological Survey, Reston, Virginia: 2007

For product and ordering information:

World Wide Web: http://www.usgs.gov/pubprod

Telephone: 1-888-ASK-USGS

For more information on the USGS — the Federal source for science about the Earth,

its natural and living resources, natural hazards, and the environment:

World Wide Web: http://www.usgs.gov

Telephone: 1-888-ASK-USGS

\footnotetext{
Any use of trade, firm, or product names is for descriptive purposes only and does not imply endorsement by the U.S. Government.

Although this report is in the public domain, permission must be secured from the individual copyright owners to reproduce any copyrighted materials contained within this report.
}

Suggested citation:

Ruleman, C.A., Crone, A.J., Machette, M.N., Haller, K.M., and Rukstales, K.S., 2007, Map and database of probable and possible Quaternary faults in Afghanistan: U.S. Geological Survey Open-File Report 2007-1103, 39 p., 1 plate 


\section{Contents}

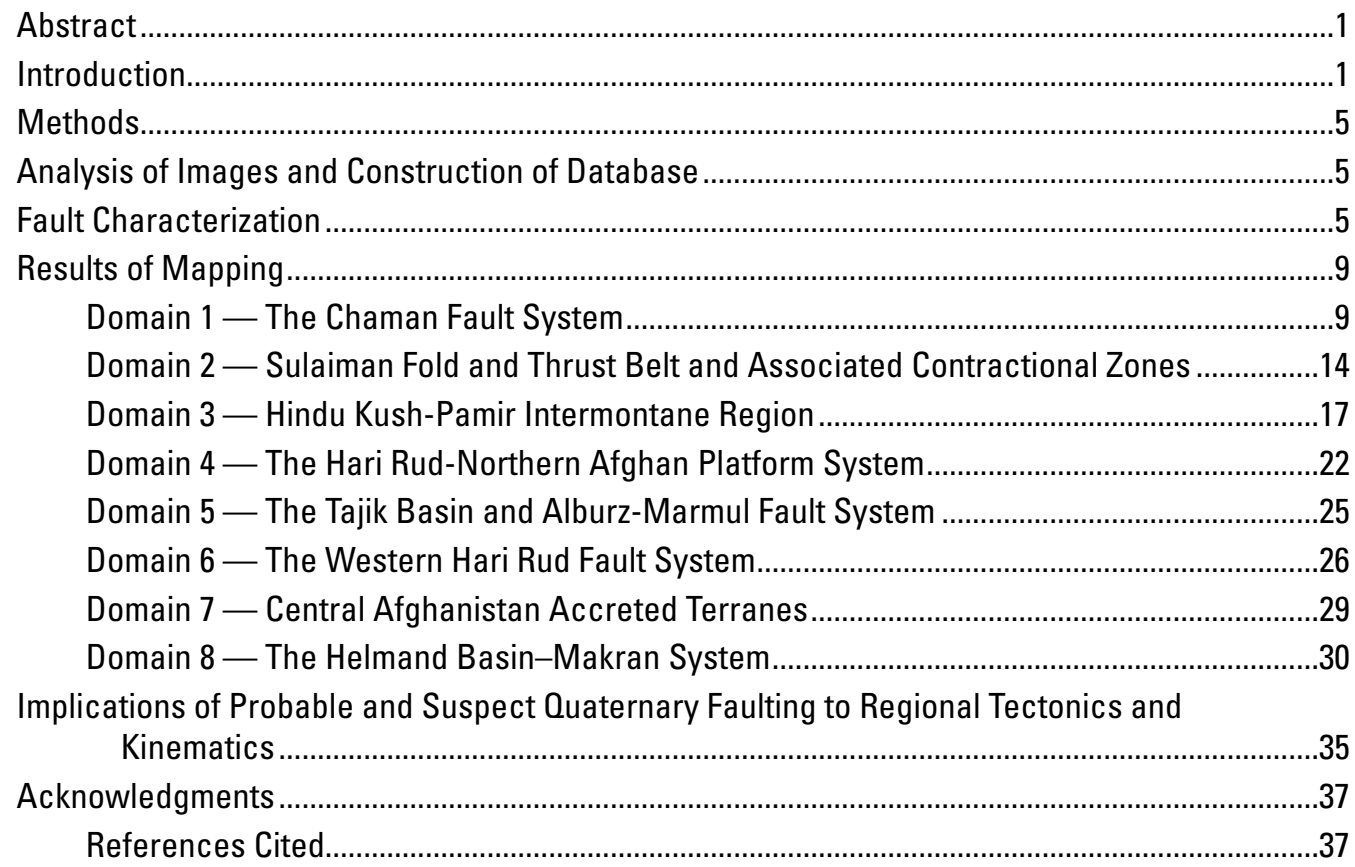

\section{Figures}

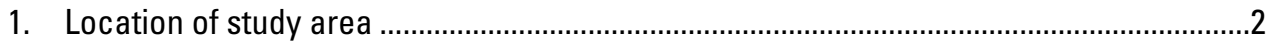

2. Shallow historic earthquakes in and surrounding Afghanistan ........................................3

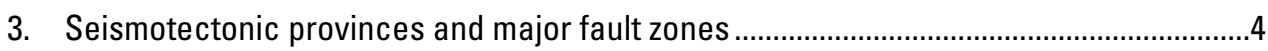

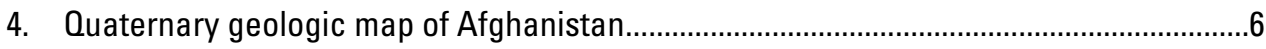

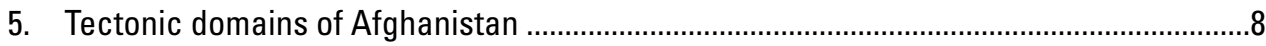

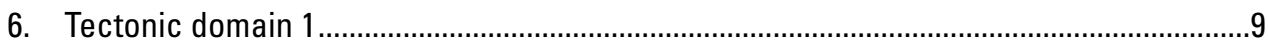

6A. Active frontal thrusts along the Chaman fault ........................................................10

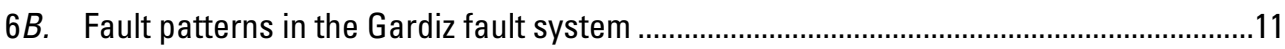

6C. Mapped strands on the Paghman fault northwest of Kabul...........................................13

7. Tectonic domain 2

7A. Landsat image of the Sulaiman fold and thrust belt .................................................

7B. Landsat image of part of the Konar fault system...........................................................

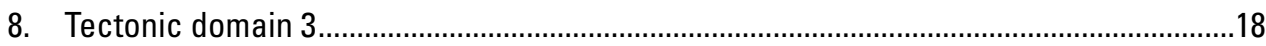

8A. Kinematics of active tectonics in northeastern Afghanistan......................................19

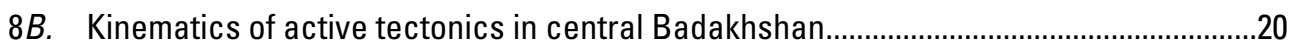

9. Category $\mathrm{C}$ faults east of Shiwa Lake, northeastern Afghanistan...................................21

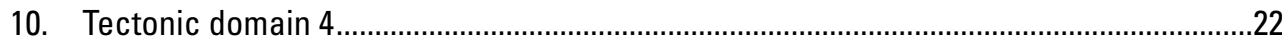

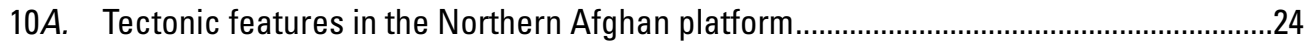

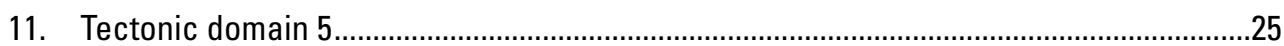

11A. Active features in the area around Mazar-e Sharif, north-central Afghanistan .............26

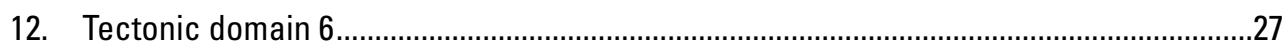


12A. Tectonic features of the western part of the Harirud fault system .................................28

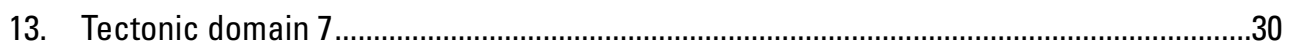

13A. Linear strike valley of the Farah Rud fault ...................................................................

13B. Pull-apart basin associated with the Navar basin system fault.........................................

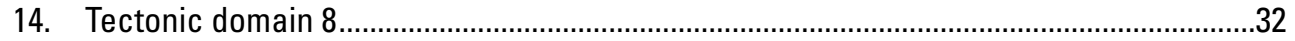

14A. Landsat image showing right-lateral movement on East Neh-West Asagie fault...........33

14B. Surface expression of category $C$ faults in the Helmand basin........................................3

15. Kinematic map of probable and possible Quaternary faults in Afghanistan ....................36 


\title{
Map and Database of Probable and Possible Quaternary Faults in Afghanistan
}

\author{
By C.A. Ruleman, A.J. Crone, M.N. Machette, K.M. Haller and K.S. Rukstales
}

\section{Abstract}

The U.S. Geological Survey (USGS) with support from the U.S. Agency for International Development (USAID) mission in Afghanistan, has prepared a digital map showing the distribution of probable and suspected Quaternary faults in Afghanistan. This map is a key component of a broader effort to assess and map the country's seismic hazards. Our analyses of remote-sensing imagery reveal a complex array of tectonic features that we interpret to be probable and possible active faults within the country and in the surrounding border region. In our compilation, we have mapped previously recognized active faults in greater detail, and have categorized individual features based on their geomorphic expression. We assigned mapped features to eight newly defined domains, each of which contains features that appear to have similar styles of deformation. The styles of deformation associated with each domain provide insight into the kinematics of the modern tectonism, and define a tectonic framework that helps constrain deformational models of the Alpine-Himalayan orogenic belt.

The modern fault movements, deformation, and earthquakes in Afghanistan are driven by the collision between the northward-moving Indian subcontinent and Eurasia. The patterns of probable and possible Quaternary faults generally show that much of the modern tectonic activity is related to transfer of plate-boundary deformation across the country. The left-lateral, strike-slip Chaman fault in southeastern Afghanistan probably has the highest slip rate of any fault in the country; to the north, this slip is distributed onto several fault systems. At the southern margin of the Kabul block, the style of faulting changes from mainly strike-slip motion associated with the boundary between the Indian and Eurasian plates, to transpressional and transtensional faulting. North and northeast of the Kabul block, we recognized a complex pattern of potentially active strike-slip, thrust, and normal faults that form a conjugate shear system in a transpressional region of the Trans-Himalayan orogenic belt.

The general patterns and orientations of faults and the styles of deformation that we interpret from the imagery are consistent with the styles of faulting determined from focal mechanisms of historical earthquakes. Northwest-trending strike-slip fault zones are cut and displaced by younger, southeast-verging thrust faults; these relations define the interaction between northwest-southeast-oriented contraction and northwest-directed extrusion in the western Himalaya, Pamir, and Hindu Kush regions. Transpression extends into north-central Afghanistan where north-verging contraction along the east-west-trending Alburz-Marmul fault system interacts with northwest-trending strike-slip faults. Pressure ridges related to thrust faulting and extensional basins bounded by normal faults are located at major stepovers in these northwest-trending strike-slip systems. In contrast, young faulting in central and western Afghanistan indicates that the deformation is dominated by extension where strikeslip fault zones transition into regions of normal faults. In addition to these initial observations, our digital map and database provide a foundation that can be expanded, complemented, and modified as future investigations provide more detailed information about the location, characteristics, and history of movement on Quaternary faults in Afghanistan.

\section{Introduction}

Afghanistan is located in central Asia in the tectonically active Alpine-Himalayan orogenic belt that developed in response to the collision between the Indian and Arabian plates and Eurasian plate in Late Paleogene to Recent (65 million years ago to the present) time (fig. 1). As the Eurasian continent was being assembled prior to 65 million years ago, numerous episodes of deformation had already shattered and buckled the crust in and around Afghanistan. As modern deformation continues in this region, moderate-to-large magnitude, potentially damaging earthquakes are common (fig. 2) and will continue to occur; these earthquakes will likely cause serious damage, not only from strong ground shaking and faults rupturing the ground surface, but also from liquefaction and extensive landsliding, as occurred during the devastating October 8, 2005, M 7.6 Kashmir earthquake in nearby northern Pakistan (Harp and Crone, 2006).

The variety of destructive and deadly hazards associated with earthquakes poses a real and serious threat to reconstruction efforts and to the economic growth and development of Afghanistan. To better understand the distribution and level of seismic hazard throughout the country, the USGS has embarked on a national seismic hazard assessment, and this 


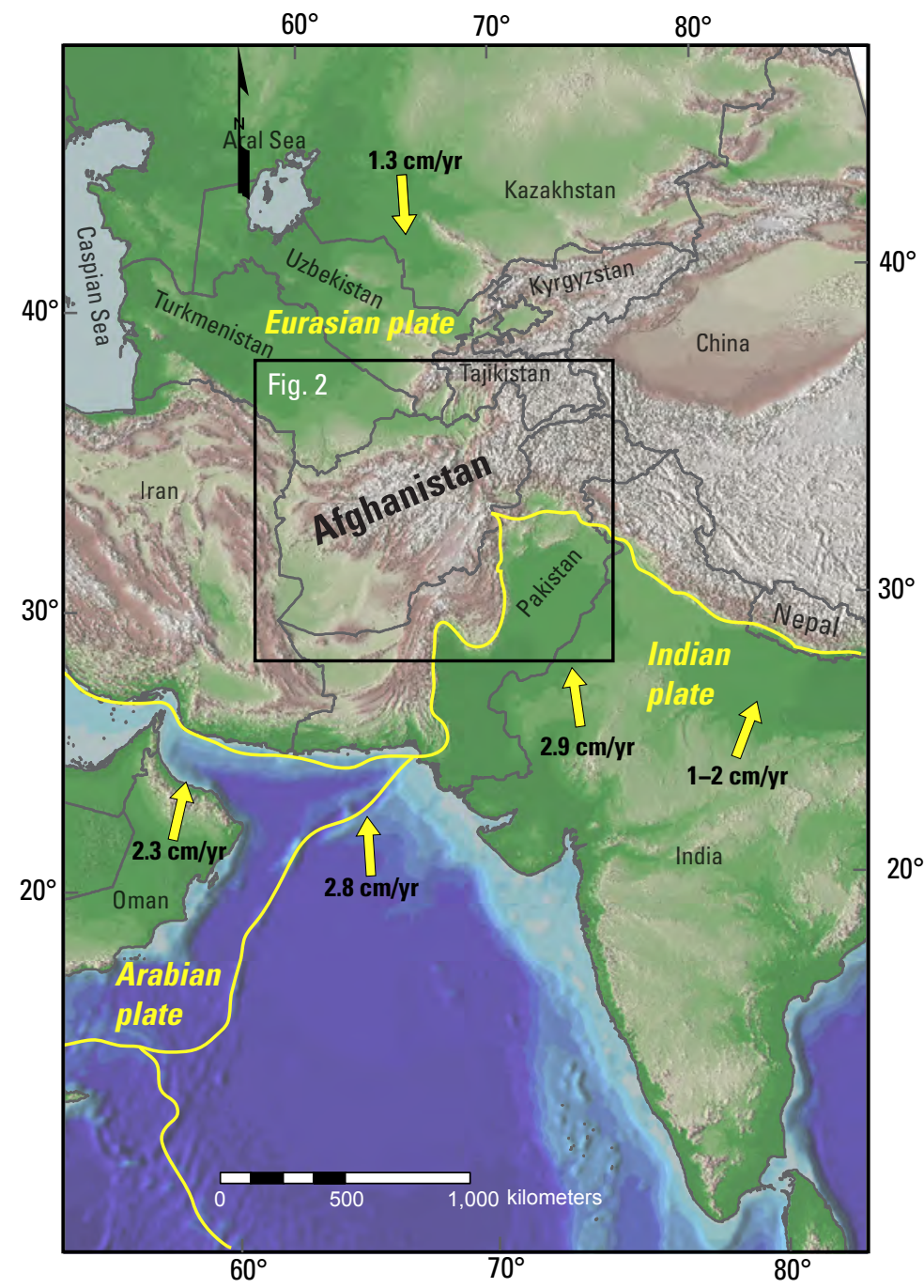

Figure 1. Location of study area in the greater AlpineHimalaya orogenic belt of Asia. Vectors show relative plate motions and velocities between the Indian, Eurasian, and Arabian plates (plate boundaries shown and labeled in yellow). Plate velocities from Jade (2004), Bird (2003), Vernant and others (2004), and Sella and others (2002). Box shows area of figure 2 .

map and database of probable and possible Quaternary faults provides valuable input into this assessment.

The Earth's crust in Afghanistan is cut by an intricate network of faults that have different orientations, ages, and directions of movement. Ancient earthquakes caused these faults to slip long ago in the geologic past, and many are now dormant and inactive. However, other faults are now active in the current tectonic regime, and some formerly inactive faults have been reactivated. The ability of a fault to move and to produce earthquakes, and its style of movement is controlled by its orientation with respect to the modern stress field. The stress field is generated by the present-day motion of tectonic plates. We know the general directions and rates of these plate motions from global and regional Global Positioning System (GPS) measurements, but details of the rates and directions of movements in Afghanistan are unknown because there are no contemporary GPS measurements in the country.

Previously published studies and the distribution of historical seismicity show that Afghanistan can be subdivided into four broad tectonic provinces that have differing geologic histories and styles of crustal deformation (Wheeler and others, 2005). As a result, each province generally has different patterns and types of fault movements (fig. 3), and each province contains a myriad of previously mapped faults, some of which could be inactive and others that could be potentially active in the modern stress field. The mapping compiled by Abdullah and Chmyriov (1977) and Doebrich and Wahl (2006) provided the basic geologic framework that we used as a guide to identify and characterize probable and possible Quaternary faults.

The distribution of historical earthquakes also provided a useful guide to where future earthquakes are likely to occur because they defined general areas where modern stresses are large enough to cause slip on faults. However, the seismicity is only a first-order approximation of the hazard because is it based on the historical and instrumental record of earthquakes, which only spans hundreds to thousands of years (Ambraseys and Bilham, 2003; Dewey, 2006). Although this may seem like a long time from an historical perspective, it is short from a geological perspective. For example, we know that the time interval (called recurrence time) between successive large earthquakes on the same part of an active fault is typically measured in several hundreds to many thousands of years. Furthermore, between these large earthquakes, many faults are seismically quiet, so the historical record of seismicity can give a false impression that certain faults are not active, and therefore not hazardous. For example, if the recurrence time on a fault is 5,000 years but our historical record is only 1,000 years long, the historical record of earthquakes will likely be too short to show the true level of hazard; as a result, historical seismicity may not identify all faults that can potentially produce large earthquakes.

To overcome this limitation, we relied on geological studies because they permit us to evaluate fault activity over time spans of thousands to tens of thousands of years. This longer time span gives us a better perspective of a fault's potential to produce damaging large earthquakes and, therefore, its associated seismic hazard. Faults that show evidence of significant movement within the last 1.8 m.y. (Quaternary period) are considered to be active or potentially active; therefore they could pose a hazard to societal and infrastructural development.

We have assigned the features on our map of probable and possible active faults to one of three categories depending on the type and characteristics of evidence indicating possible Quaternary displacement. We emphasize that our map is a qualitative, reconnaissance-level evaluation of potentially hazardous features and helps define regions that have varying 


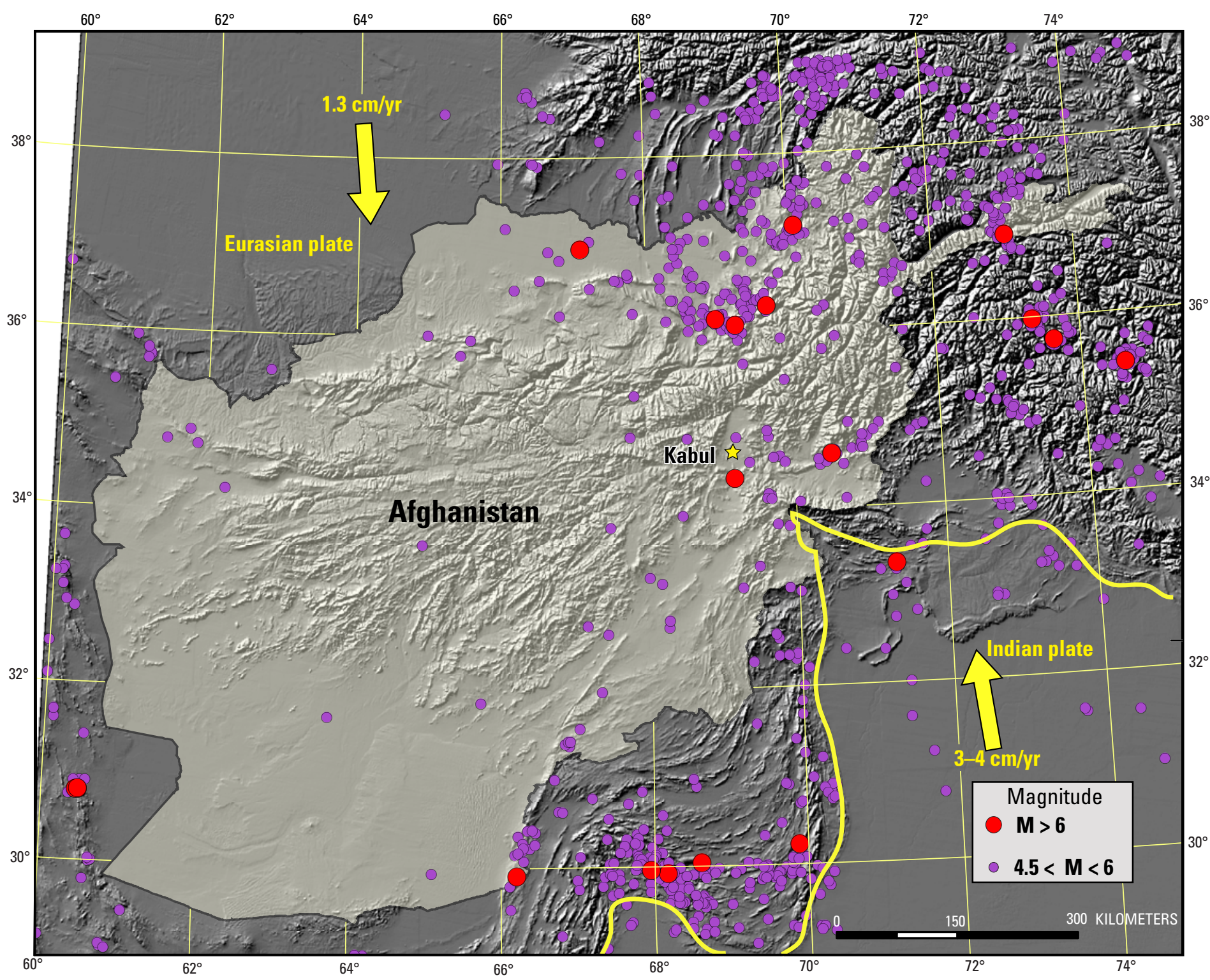

Figure 2. Shallow ( $<35 \mathrm{~km}$ deep) historical earthquakes (Dewey, 2006) in and surrounding Afghanistan (light-shaded region). Open arrows show direction and rate of relative plate motion between Indian and Eurasian plates (Sella and others, 2002; Bird, 2003). Plate boundaries are shown in yellow. The abundant earthquakes and active faulting in Afghanistan are caused by the Indian plate moving northward beneath Eurasia at a rate of approximately $3-4 \mathrm{~cm} / \mathrm{yr}$. This collision has uplifted the Himalayan, Hindu Kush, and Pamir Mountains (unlabeled high terrain in northeastern section of map). 


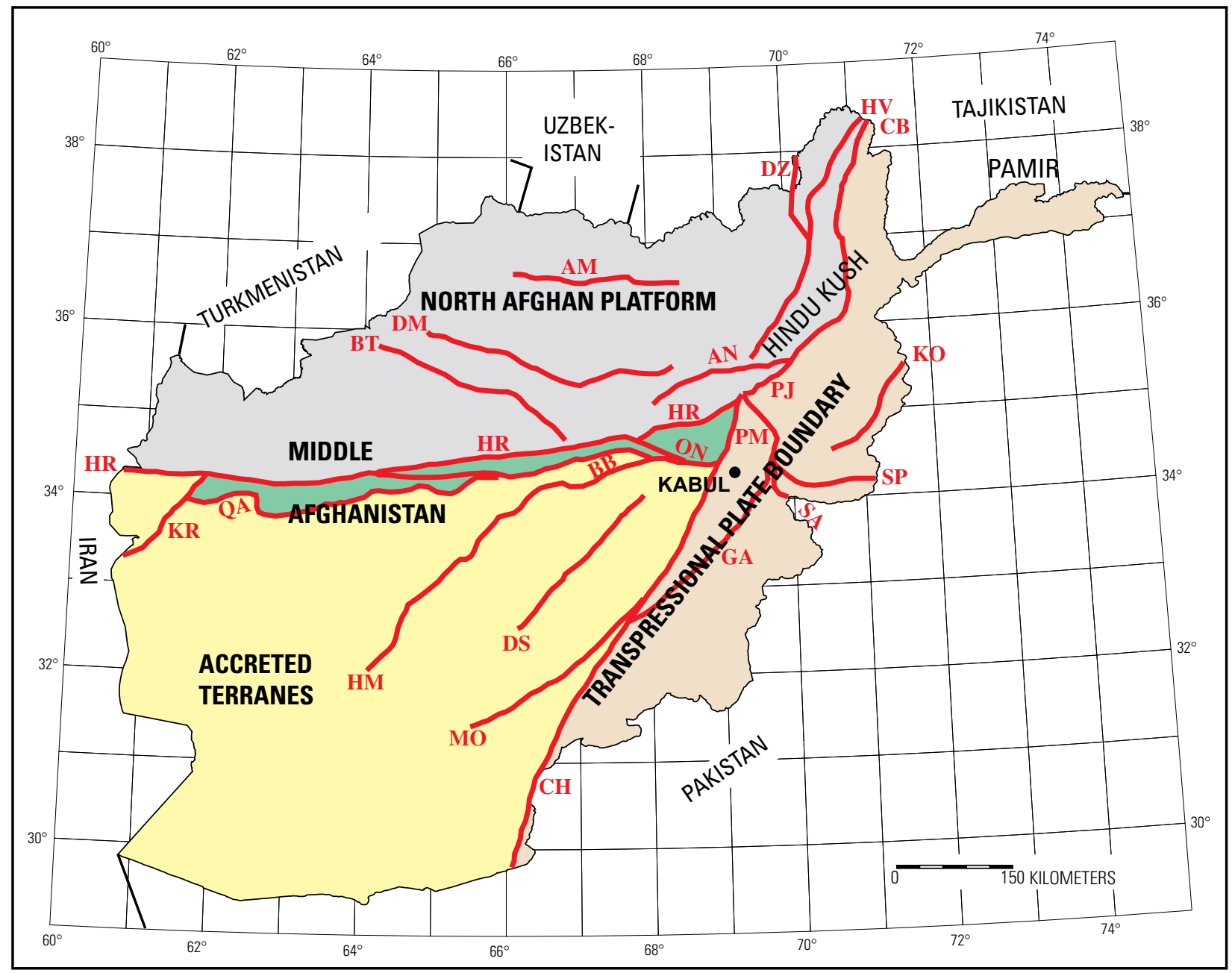

Figure 3. Seismotectonic provinces and major fault zones (bold red lines). Abbreviations of fault names: AM, Alburz Marmul; AN, Andarab; BB, Bande Bayan; BT, Bande Turkestan; CH, Chaman; CB, Central Badakhshan; DS, Dorafshan; DZ, Darvaz; DM, Dosi Mirzavalan; GA, Gardez; HR, Hari Rud; HM, Helmand; HV, Henjvan; KR, Kaj Rod; KO, Konar; MO, Mokur; ON, Onay; PM, Paghman; PJ, Panjshir; QA, Qarghanaw; SA, Sarobi; SP, Spinghar. Modified from Wheeler and others (2005).

levels of potential seismic hazard. Where mapped features are abundant, the seismic hazard is likely higher than in areas where there are few or no features. In-depth, detailed geological field studies are required to fully assess the hazard of individual features, but these types of field studies/investigations are beyond the scope of this study. However, the data presented here is the first systematic evaluation of probable and possible active faults nationwide, and provides a starting point from which future detailed studies can be based.

The features shown on the map are based on our interpretation of remote-sensing imagery. We mapped these features based solely on their expression in the landscape, and we infered that they all could be potentially active Quaternary faults and therefore could be sources of strong ground motion. However, this inference of Quaternary activity needs to be confirmed from ground-based studies because a number of mapped features could be inactive faults or lineaments that formed in former tectonic episodes.

To develop preliminary seismic hazard maps of Afghanistan, USGS scientists have assembled a comprehensive catalog of historical seismicity (Dewey, 2006). When combined with our longer-term geological perspective of fault activity, it will be possible to develop a preliminary probabilistic assessment of seismic hazards throughout the country. This type of assessment is an important source of information that can be used by engineers to help design critical facilities such as power plants, dams, pipelines, major roads, and similar infrastructure that is more able to withstand the effects of strong earthquakes. Hazard maps also help officials understand and appreciate the scope and level of seismic hazard in various parts of the country and, hopefully, anticipate how to prepare for, and respond to, a major earthquake. 


\section{Methods}

We first compiled previously published reports and information that related to Quaternary faulting and the geomorphology and stratigraphy of Quaternary deposits (Ruleman, 2005). This information, combined with data on the regional geological structures and plate movements (Wheeler and others, 2005) and historical seismicity (Dewey, 2006), provided an overall perspective of the past geological history and current distribution of earthquakes in the region. Published geologic mapping (Abdullah and Chmyriov, 1977) highlighted specific features that needed to be carefully examined. With this background information, we systematically examined calibrated Landsat ETM (Enhanced Thematic Mapper) satellite imagery (Davis, 2006), 90-m-resolution, shaded-relief maps developed from SRTM (Shuttle Radar Topographic Mission) data (Chirico and Barrios, 2005), selected images from GeoEye's IKONOS, and Digital Globe's QuickBird imagery.

Our interpretations of possible young faulting is based on the presence of apparently displaced young (Quaternary) landforms and deposits, which are commonly located in valleys and along the margins of mountain ranges. In regions where Quaternary deposits and landforms are rare or absent, such as in steep mountainous terrain or other upland settings, we focused on prominent and continuous escarpments and strong lineaments in bedrock. Evidence indicative of Quaternary movement is less definitive on these features because of the scale and size of these features, and in some cases, their continuous surficial expression in rugged, eroding terrain. Even though the evidence of young movement on these features may not be compelling, we mapped them because they warrant additional evaluation.

As a result of our mapping and characterization, we subdivided the country into eight general tectonic domains based on similarities in the overall patterns and types of features in each domain and characteristics that suggest a similar dominant style of deformation. The features and characteristics of each domain are subjective, but we believe that this grouping contributes to an improved understanding of the styles and patterns of Quaternary deformational mechanics and should help develop kinematic models of the regional deformation.

\section{Analysis of Images and Construction of Database}

We relied heavily on rectified, color-balanced Landsat imagery for our mapping (Davis, 2006). We imported the images into ArcMap and ArcInfo software and geo-referenced the images into a global framework. The images were panchromatically enhanced to yield color images that have a resolution of $14.25 \mathrm{~m}$ (about $46 \mathrm{ft}$ ). We used images that replicate natural colors by combining bands $7+3+1$ and $7+4+1$ (Davis, 2006). In addition, we used high-resolution (about $1 \mathrm{~m})$ IKONOS and Quickbird imagery in a few selected areas where we hoped that the enhanced resolution would allow us to see and measure offset of small-scale features.

We digitally mapped individual features using ArcMap software. Because of the resolution limit of the Landsat imagery, we could only map features at a maximum scale of about 1:50,000. We assigned a name and fault ID number to each feature (pl. 1) and linked it to an attribute table that contains descriptive information about the structure. We assigned each feature to an activity category (described below), described traits of its surface expression, characteristics of offset landforms, and where possible, an order-of-magnitude estimate of its slip rate. The Arc software calculated each feature's length and overall orientation. For some features we could identify stream deposits and other landforms that were laterally displaced, and where possible, we mapped the lateral extent of possible surficial ruptures, focusing on areas where the morphology of the landscape suggests active faulting. The resolution of the imagery limited our ability to measure small offsets; offsets had to exceed $30 \mathrm{~m}$ to be detectable. Offsets of this size are large enough that they must be the result of multiple movements on a fault, so those features that have measured offsets must have significant roles in the contemporary tectonics of Afghanistan.

\section{Fault Characterization}

Previous geological studies in Afghanistan have broadly defined the locations of major Neogene ( $<25$ m.y.) faults and fault zones. In this study, we more accurately locate and map individual strands of fault systems that have Quaternary movement, and have identified previously unreported possible Quaternary faults. Because this was done systematically throughout Afghanistan, we recognized patterns of faulting that offer new insight into regional tectonics, and place limits on viable models of modern deformation. Because our interpretations of lineaments, dip-slip faults, and other features in a regional kinematic framework are strictly preliminary, the combination of our mapping and the resultant digital database provide a basic foundation and starting point for compiling geological data that can be utilized for preliminary seismic-hazard analysis, and can be updated as new information is collected.

For this map, we characterized features based on their continuity and expression in young (Quaternary) geologic deposits and on the approximate amount of vertical and(or) horizontal displacement (estimated in meters) of a specific landform. Previous mapping of the Quaternary geology of Afghanistan (Abdullah and Chmyriov, 1977; Doebrich and Wahl, 2006) provides general information about the relative ages of some deposits and landforms (fig. 4), but their absolute ages are largely unknown. In the absence of absolute age information for specific deposits, it is impossible to determine fault slip rates. However, we can broadly estimate slip rates by estimating the age of a deposit, that is, Holocene versus latest Pleistocene or late Pleistocene on the basis of its general geomorphic expression in the landscape. Even this type 


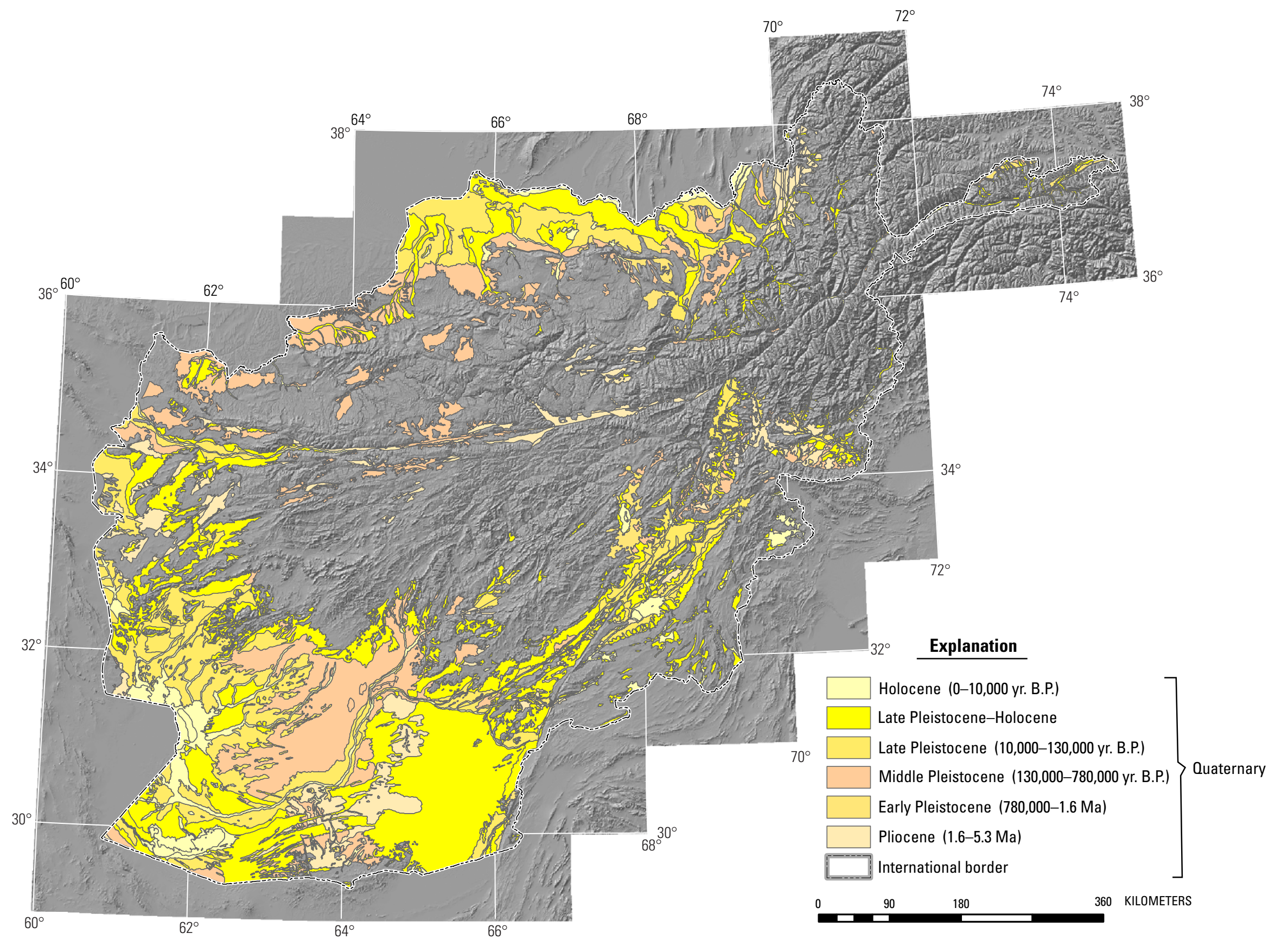

Figure 4. Quaternary geologic map of Afghanistan (from Doebrich and Wahl, 2006). Units are listed chronologically in the explanation. The Quaternary geology was previously mapped by Abdullah and Chmyriov (1977) and is primarily confined to large basins in southwestern and north-central Afghanistan. The lack of previously mapped Quaternary deposits in central and northeastern Afghanistan required that we rely on the geomorphic expression of features on the high-resolution imagery to identify active faults. B.P., before present; Ma, million years. 
of generalized slip-rate estimate is a helpful indicator of the level of hazard associated with a feature. Ultimately, we need to conduct ground-based studies at selected locations to obtain critical data on the age of deposits and the amount of offset in order to determine more accurate, geologically based slip rates.

Earthquakes that rupture the ground surface displace geomorphic surfaces and geologic deposits vertically, horizontally, or obliquely (a combination of vertical and horizontal offset).

The Landsat imagery only gives us a vertical, two-dimensional view of the landscape, and as a result, is best suited to detect horizontally offset features, such as those along the left-lateral strike-slip Chaman fault (fig. 3). Because of the imagery's vertical perspective, it is far more difficult to identify faults that have mainly vertical movement, and thus more difficult to measure the amount of vertical displacement.

Because of the constraints imposed by the imagery's resolution and the interpretive nature of our work, we developed a three-category scheme to qualitatively characterize the expression of our mapped features in the landscape. The scheme also reflects our confidence in the role that they play in the contemporary tectonics of Afghanistan. Our categories are:

- Category A:Major structures that are prominently expressed in the landscape and are likely to play an important role in determining the modern tectonics and seismic hazard.

- Category B:Minor structures that are distinctly expressed in the landscape and that could be a significant contributor to seismic hazards.

- Category C:Structures that have a subtle expression in the landscape or that have limited or poor expression in Quaternary deposits, but could possibly contribute to seismic hazards.

Features in category A are likely to be important seismic source zones and, therefore, contribute significantly to Afghanistan's seismic hazards. These features have a distinctly visible physiographic signature on imagery that is mappable at a scale of 1:50,000. Based on the geologic mapping of Abdullah and Chmyriov (1977), these faults typically offset late Pleistocene and Holocene deposits and landforms and are generally marked by continuous fault scarps that offset older and younger stream deposits and landforms. They may have geomorphic evidence of fault activity that extends back $100,000 \mathrm{yr}$ or more. The larger, more active faults may also be associated with historical earthquakes. Even young (late Holocene) stream channels are commonly displaced. In optimum geological settings, such as at major alluvial fans, progressively older deposits are displaced by increasingly greater amounts, which is clear evidence of repeated activity over significant intervals of geologic time. Based on studies of faults elsewhere in the world (for example, the San Andreas fault in the western U.S.) that are in similar geologic and climatic settings as Afghanistan, we speculate that faults that have this type of expression in the landscape probably have slip rates on the order of $10 \mathrm{~mm} / \mathrm{yr}$ or more.
Category B faults are commonly mappable in surficial (Quaternary) deposits and in areas of bedrock, but overall their expression is less continuous than category A features. The discontinuous nature of the scarps or lineaments suggests an overall lower slip rate and probably longer time intervals between surface-rupturing earthquakes. Because of this relatively lower activity rate, parts of the fault scarps may be eroded or buried by younger deposits, resulting in a discontinuous trace. Bedrock fault scarps are discontinuous or absent where active fluvial channels and younger stream deposits may have buried scarps; however, geomorphic development of piedmont deposits and landforms (for example, deflection of active fluvial networks and active stream incision of uplifted benches) have been influenced by fault activity. In many cases, offsets across these faults are measurable on landforms whose age can be defined in terms of a relative chronology. Based on comparison with other global faults, faults that have this type of general surface expression (for example, the Wasatch fault, Utah and Karakoram fault of western China) typically have slip rates on the order of 1 to $10 \mathrm{~mm} / \mathrm{yr}$.

Features that are assigned to category $\mathrm{C}$ typically are structures that have evidence suggestive of Quaternary movement, but the evidence is subtle at the scales of our imagery. For these structures, it is difficult to quantify the amount of surface displacement or the age of the offset landforms. In many cases, these faults are expressed as bedrock lineaments, shutter ridges, and (or) as fault-controlled streams and drainages; the fault-controlled drainage patterns can extend for distances of tens to hundreds of kilometers. On the Landsat imagery we can map these features, but we cannot confidently measure the amount of displacement or estimate slip rates. Many of these features are in rugged mountainous regions or in bedrock terrain where Quaternary deposits and landforms are rare to absent along most or all of the feature's length. However, based on erosion rates and the extensive history of glaciation in the high alpine regions of Afghanistan, the presence of these lineaments suggest a Quaternary age for category $\mathrm{C}$ features. We also categorized features that have mainly vertical displacement as category $\mathrm{C}$ structures because of the difficulty in measuring vertical displacements on the Landsat imagery.

\section{Results of Mapping}

Based on tectonic, geomorphic, and physiographic analyses and interpretations, we subdivided Afghanistan into eight tectonic domains, each having different general patterns and characteristics of mapped features (fig. 5). Each domain has distinct physiographic and geomorphic qualities that we interpret to reflect different styles of Quaternary deformation. In some domains, pre-Quaternary faults are cut by younger (active) faults that have a different orientation; these relations indicate that a change in the stress field has changed the mechanics of the deformation. Other regions have faults that show evidence of sustained activity throughout Neogene time $(<25 \mathrm{Ma})$. 


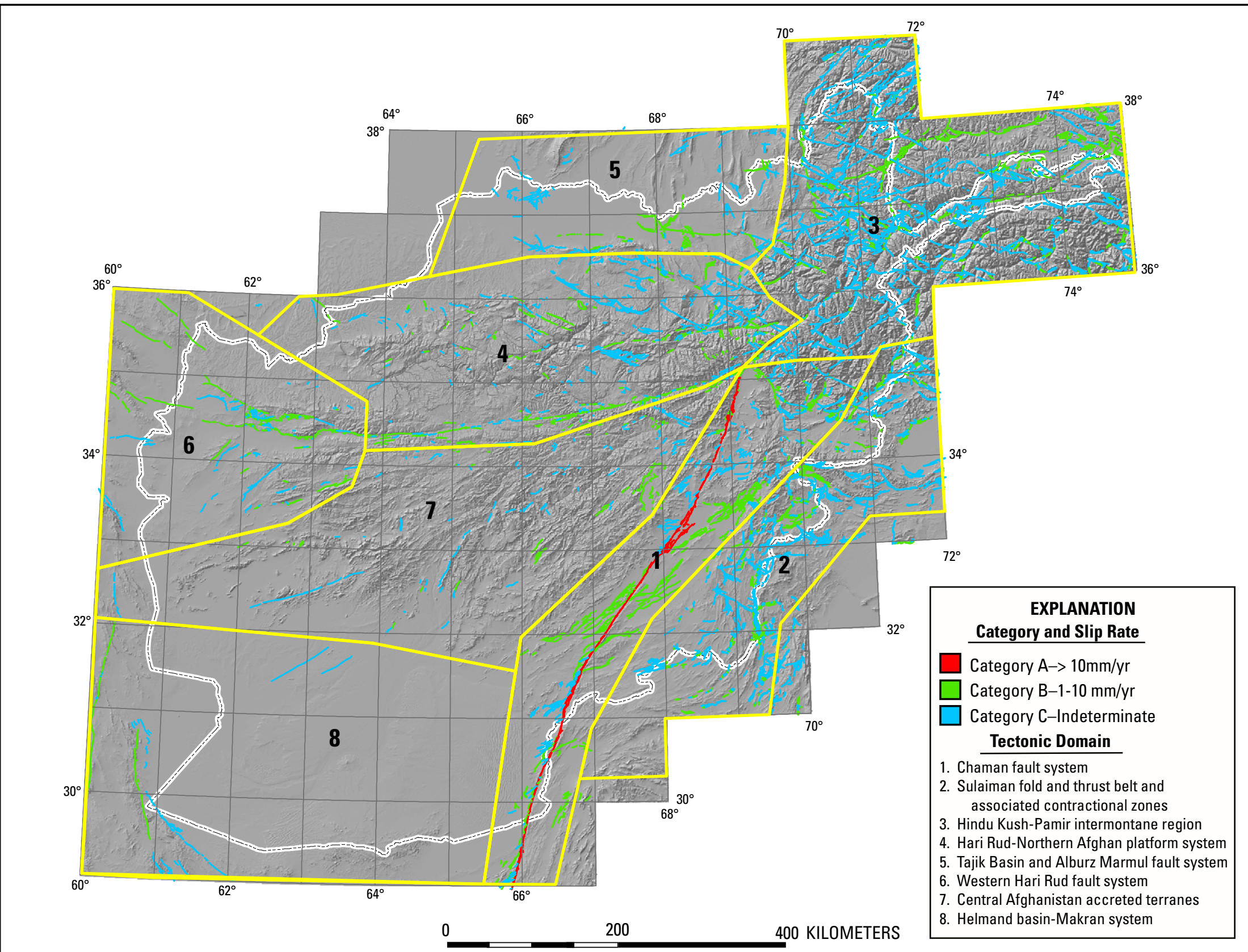

Figure 5. Probable and possible Quaternary faults and eight tectonic domains (shown by yellow boundaries) of Afghanistan. Domains are defined by regions having a similar structural style of deformation and, as a result, a similar physiographic expression. See the text for discussions of each domain. 


\section{Domain 1 - The Chaman Fault System}

The Chaman fault system (pl. 1, no. 65, 66, 91, 93-101, and 103-105) is a major left-lateral strike-slip fault system that accommodates much of the differential movement between the Indian and Eurasian plates in southeastern Afghanistan and adjacent Pakistan. The fault system has reported slip rates of 19-24 mm/yr (Lawrence and others, 1992), which assigns it to a category A fault system in our scheme (fig. 6). The geomorphic expression of the fault system in Quaternary deposits varies along the 860-km-long fault trace. Following Wheeler and others (2005), we subdivided the Chaman fault system into four subsidiary systems to better distinguish between different styles of Quaternary deformation. From south to north, they are: 1) Chaman fault, 2) Mokur fault, 3) Gardiz fault, and 4) Paghman fault (fig. 6).

The main Chaman fault is approximately $650 \mathrm{~km}$ long in our mapped area, and terminates near the southern margin of

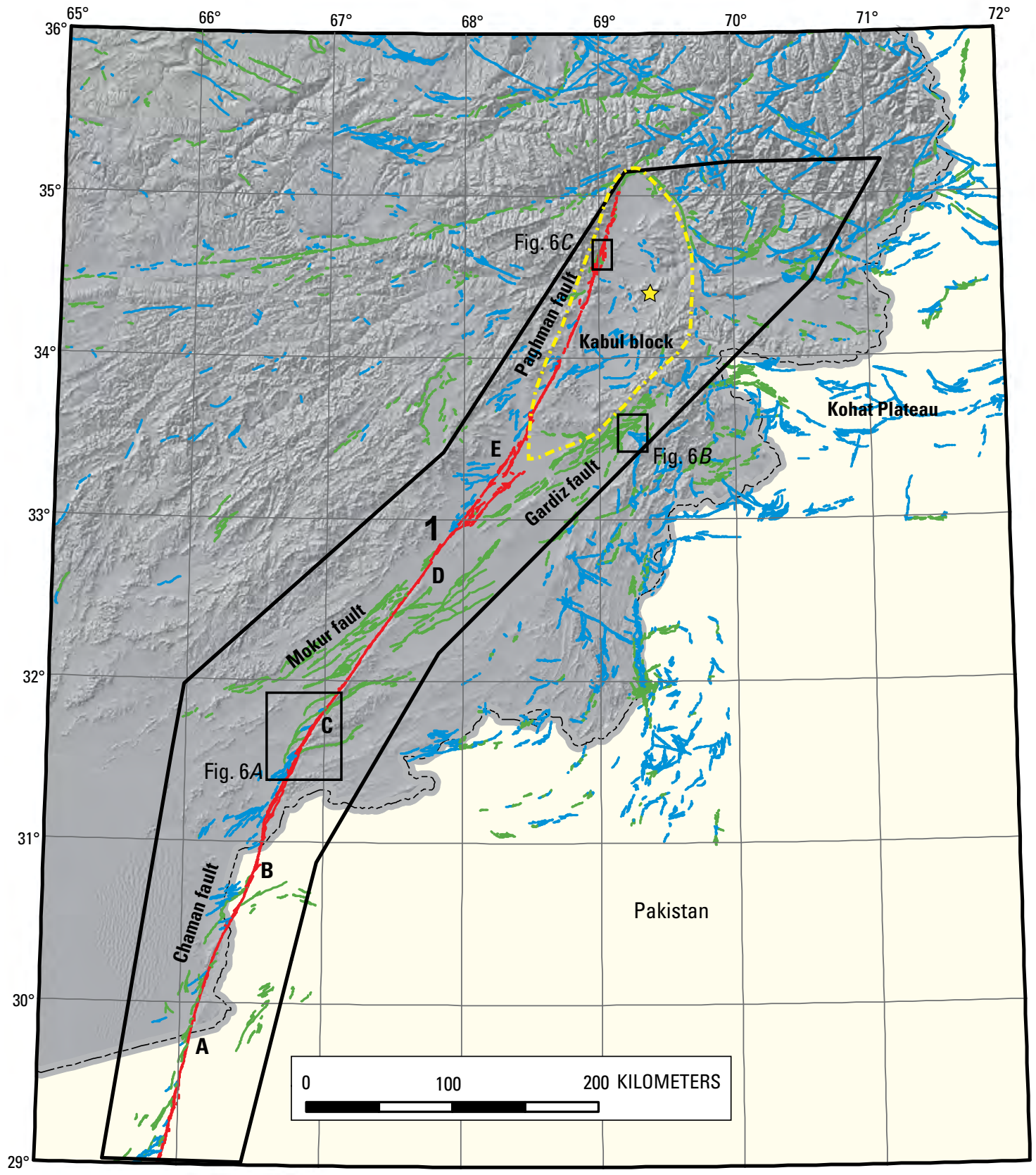

Figure 6. Tectonic domain 1-the Chaman fault system outlined in black. Dashed yellow line shows approximate boundary of the Kabul block. Sections of Chaman fault shown by letters A-E. Fault categories are category A, red; category B, green; and category C, blue. Yellow star shows location of Kabul. 
the Kabul block. The fault trace ranges from linear zones that are less than $1 \mathrm{~km}$ wide to zones comprised of multiple strands where conjugate and Reidel shear systems merge with the main trace. Along the southern section (pl. 1, no. 94), we mapped eastdipping thrust faults on the western side of the main fault that are second-order features; they formed as a result of left-lateral slip and compression on the master fault (fig. 6A). Some of these thrust faults are more than $20 \mathrm{~km}$ long and extend more than $10 \mathrm{~km}$ west of the main fault trace. The scale of these secondorder features indicates that the cumulative amount of left-lateral movement on the Chaman fault must be measured in many tens, if not hundreds, of kilometers. Multiple strike-slip fault strands are proximal to these thrust faults, indicating a complex interplay between left-lateral faulting and northwest-directed compression. Along this part of the fault system, the northeast-trending strike-slip scarps are linear, continuous features on piedmont alluvium and at the contact between bedrock and young Quaternary deposits. At the contact between piedmont alluvium and mountain-front bedrock, the fault scarps are west-facing, discontinuous, and arcuate. To the north, these multiple strands merge into a single main linear trace of the Chaman fault, which shows evidence of mainly left-lateral strike slip (pl. 1, no. 91).

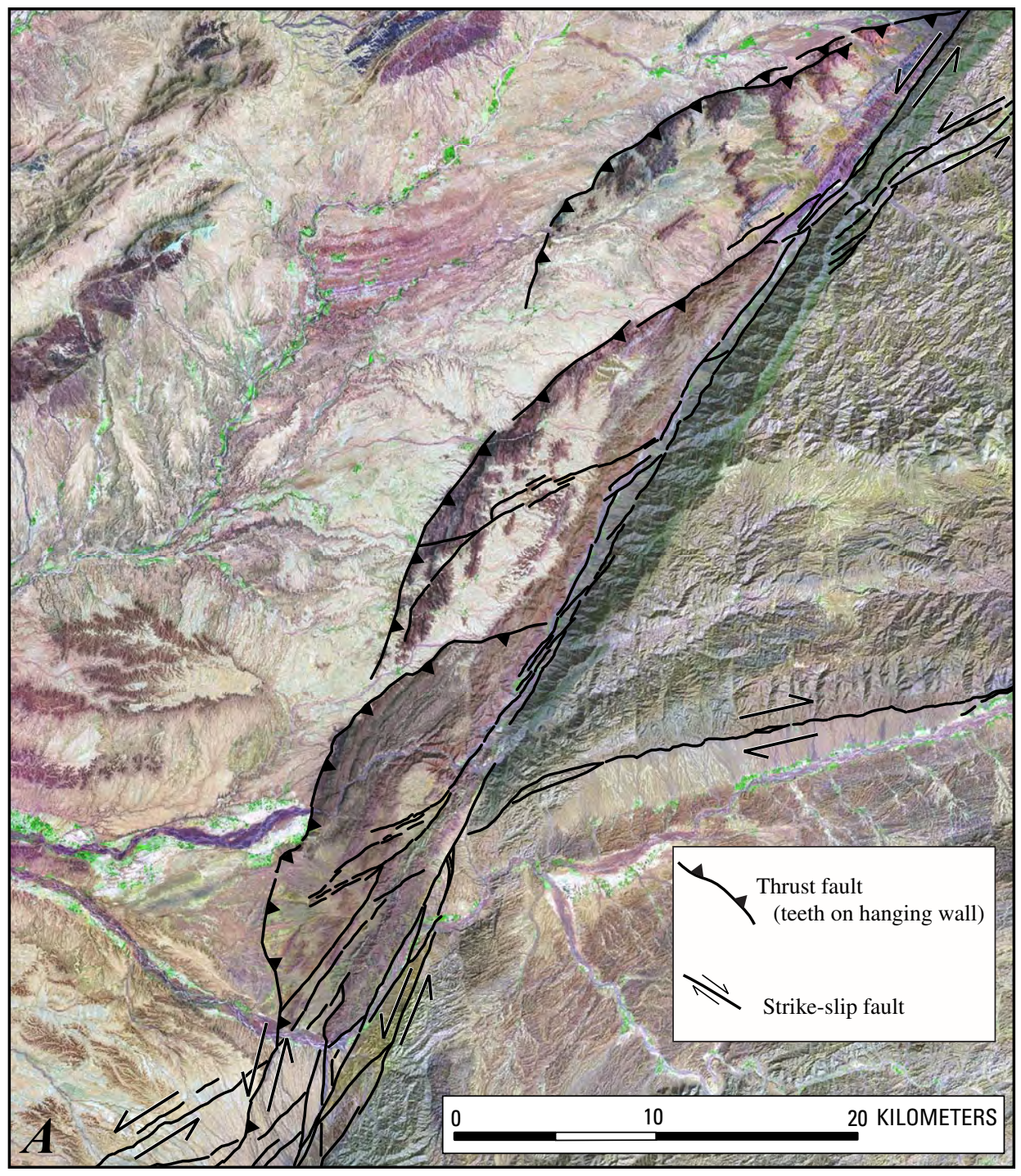

Figure $6 \boldsymbol{A}$. Active frontal thrust faults along western margin of the left-lateral strikeslip Chaman fault (pl. 1, no. 94). Image is a panchromatically enhanced Landsat image that merges bands $7+4+1$. The strike-slip strands of the Chaman fault system extend from the upper right to the bottom left of the view. The arcuate, northwest-directed, frontal thrust faults are second-order structures that result from the combination of compression and strike-slip motion on the Chaman fault system. See figure 6 for location. 
Northward near the junction between the Mokur and Gardiz faults (fig. 3), the north-northeast-trending Chaman fault splays into multiple, synthetic strands that show clear evidence of leftlateral displacement in Quaternary basin deposits (pl. 1, no. 86). The Mokur fault (pl. 1, no. 92) shows evidence for Quaternary activity and has northeast-trending, continuous, linear fault scarps on piedmont and intra-basin alluvium of the Tarnak River Valley. Northwest of the main fault trace, older, discontinuous, arcuate scarps are present along the range front, suggesting southeastverging thrust fault activity along this fault system.

South of the Kabul block (fig. 6A), the section east of the main Chaman fault system (pl. 1, no. 65) splays into the northeast-trending Gardiz fault (fig. 6B) and associated subsidiary faults. The southern section of the Gardiz fault is marked by a 7 - to 8 -km-wide zone of northeast-trending linear, discontinuous scarps on piedmont alluvium (pl. 1,

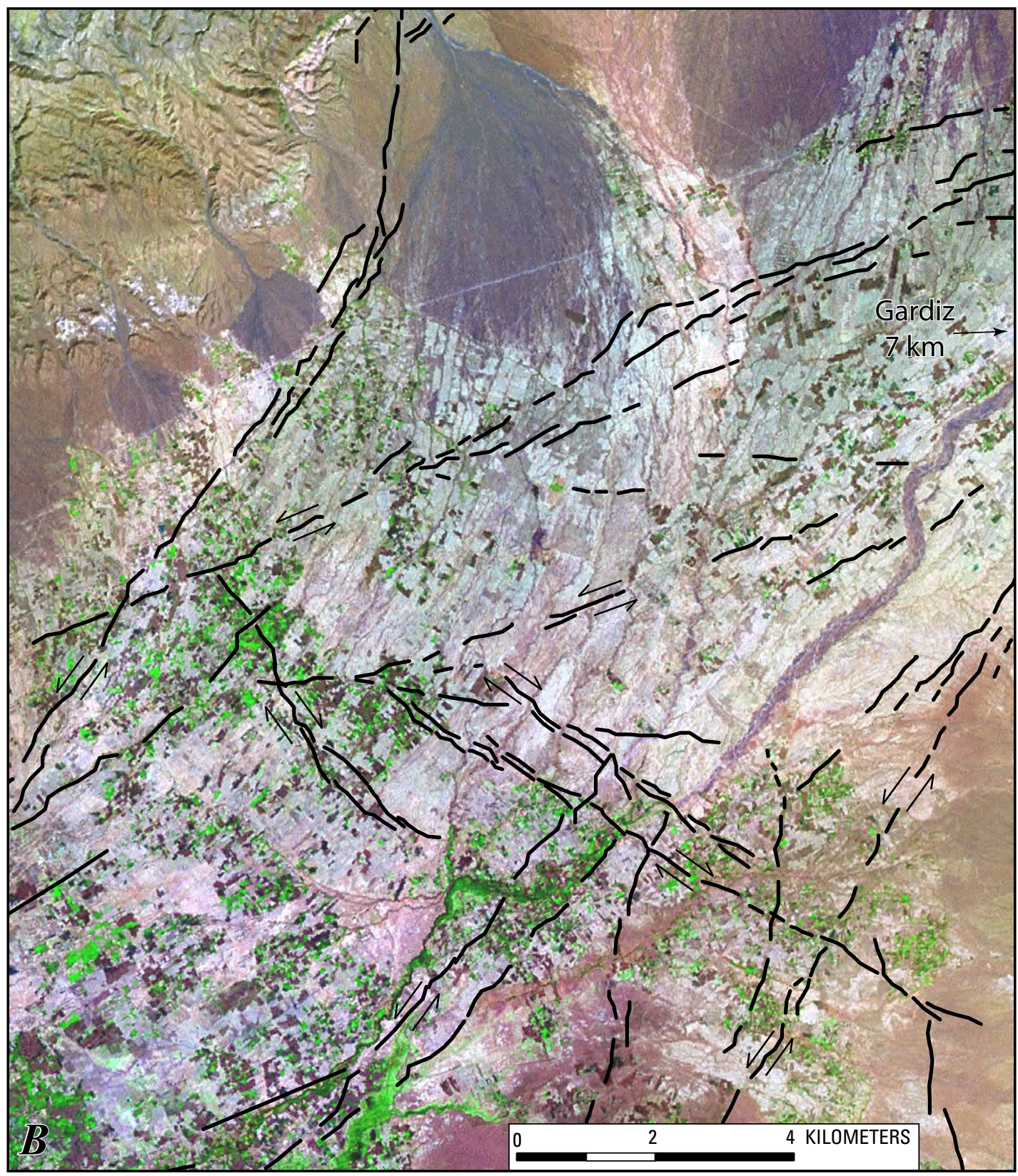

Figure 6B. Fault patterns in the Gardiz fault system. Intra-basin faults showing synthetic and antithetic faults in the left-lateral, strike-slip Gardiz fault system. Image is a panchromatically enhanced Landsat image that merges bands $7+4+1$. Black lines show probable or possible faults, arrows show directions of lateral slip. Structures that strike northeasterly have a left-lateral sense of slip, whereas structures that strike northwesterly have a right-lateral sense of slip. See figure 6 for location. 


\section{Map and Database of Probable and Possible Quaternary Faults in Afghanistan}

no. 85). Intensely folded and faulted rocks exposed in bedrock highlands show evidence of compressional structures that formed during initial contraction of the Katawaz Basin (fig. 7), but Quaternary activity indicates primarily strikeslip faulting. The northern part of the Gardiz fault (pl. 1, no. 68) consists of a complex zone of conjugate and Riedel shear zones in a dominantly left-lateral, strike-slip fault zone (fig. 6b). In this region, the fault zone has northeast- and northwest-trending, continuous, linear scarps on piedmont and river valley alluvium. We found evidence of right-lateral and left-lateral offsets on Quaternary deposits. At its northern end, the Gardiz fault (pl. 1) terminates in a complex junction with the Sorubi fault (no. 57, Plate 1) and the western part of the Safed Koh-Main Boundary thrust system (pl. 1, no. 74). Northeast of this junction, the Konar fault (pl.1, no. 52) (fig. 3) shows evidence of active left-lateral faulting; continuous fault scarps are present on piedmont landforms and on Quaternary deposits of various ages.

The Sorubi fault (pl. 1, no. 50), northeast of Kabul, coincides with a precipitous, linear range front that has scarps along the bedrock-colluvium contact, but no scarps are on adjacent piedmont alluvium. Displacement on this fault appears to be primarily dip-slip (vertical), but it may also have a small dextral (right-lateral) component of slip. Microearthquake studies support some right-lateral motion on the Sorubi fault (see Prevot and others, 1980). East of the Sorubi fault, we interpret discontinuous, arcuate fault scarps (pl. 1, no. 51) on valley alluvium and cutting across bedrock spur ridges to be southwest-verging thrust faults.
Along the eastern margin of the Kabul basin, we mapped a few discontinuous, linear scarps (pl. 1, no. 58) on older range-front alluvium, but did not see scarps on younger alluvium associated with the last major cycle of fan deposition, which is probably late Pleistocene in age. We interpret these discontinuous scarps to be normal faults that are part of an extensional system associated with the rotation and wrenching of the Kabul block between the Sorubi-Konar fault system to the east and the Chaman-Paghman fault system to the west.

The northern section of the Chaman fault system corresponds to the Paghman fault (pl. 1, no. 59), where primarily left-lateral strike-slip faulting to the south transitions into a region of apparent sinistral (left-lateral) oblique-thrust faulting and dip-slip displacement (fig. 6C). The Paghman fault trends north and northeast and is marked by continuous, linear and arcuate fault scarps on piedmont alluvium and at the mountain front contact between alluvium and colluvium. We were able to measure the left-lateral displacement of active streams and river channels, which demonstrates very young movement on some fault strands. In addition, the deposits from old alluvial fans have been left-laterally transported considerable distances $(\geq 155 \mathrm{~m}$ ) from their original sources such that fans are now located adjacent to small mountain drainages that could not possibly have been the source of such a large fan (fig. $6 C$ ). Thus, the geomorphic evidence shows that recent movement has occurred on the Paghman fault and that this movement has been sustained throughout much of Quaternary time. 


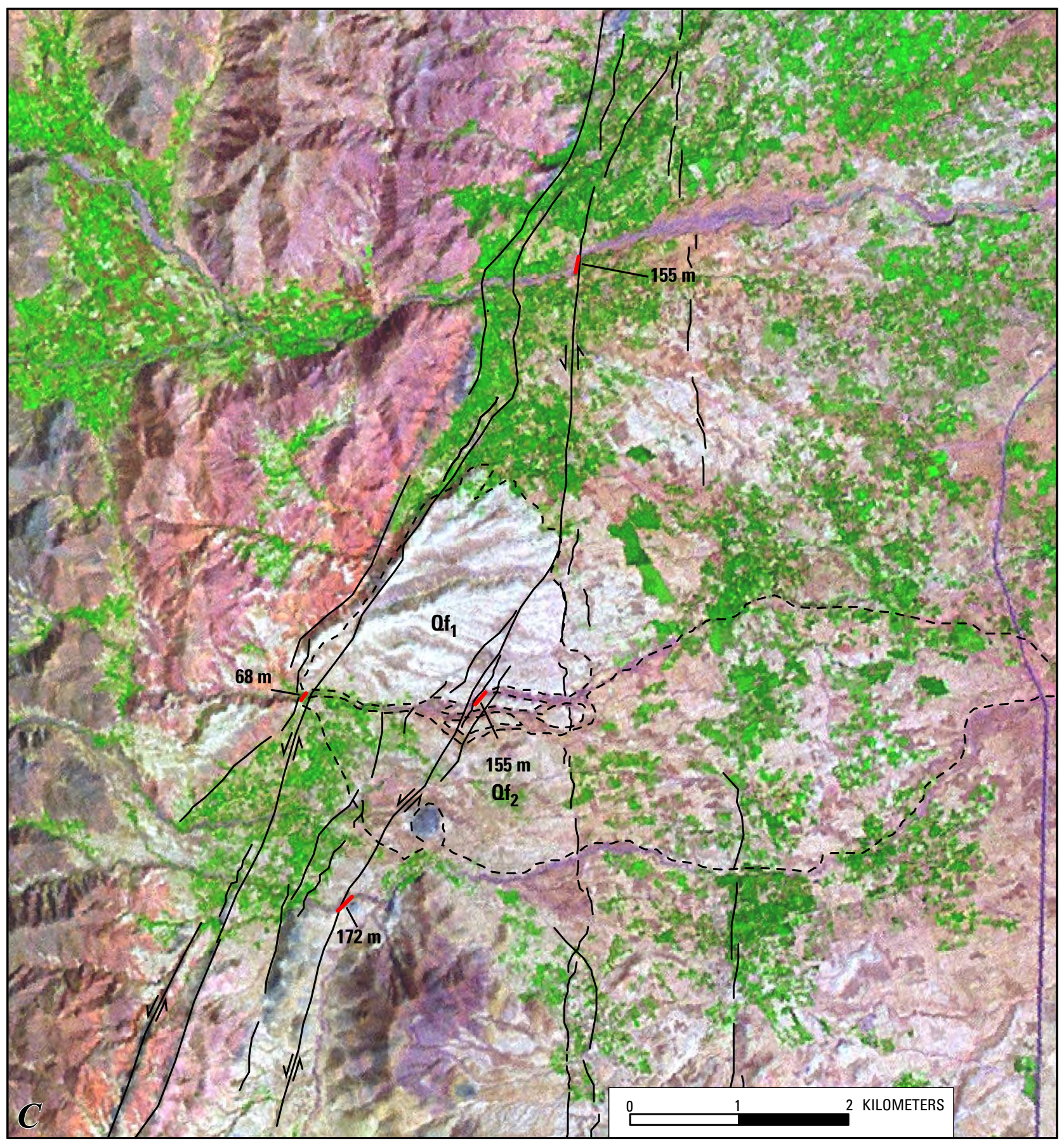

Figure 6C. Mapped strands on the Paghman fault (pl. 1, no. 59) northwest of Kabul. Black lines are mapped fault strands on Quaternary alluvium and bedrock; arrows show directions of movement on fault strands. The fault zone contains multiple strands that offset stream channels varying amounts. Measurements, in meters, show where major streams have been left-laterally displaced by faults. Red solid lines show selected measurements. The large, white, old alluvial fan $\left(\mathrm{Qf}_{1}\right)$, has been transported northward along the fault relative to it original source drainage, and a new, younger fan $\left(\mathrm{Qf}_{2}\right)$ is being deposited in its previous position. Image is a panchromatically enhanced Landsat image that merges bands $7+4+1$. See figure 6 for location. 


\section{Domain 2 - Sulaiman Fold and Thrust Belt and Associated Contractional Zones}

Domain 2 includes the region from the main Sulaiman fold-and-thrust belt of western Pakistan and southeastern Afghanistan northeastward to the Main Boundary (pl. 1, no. 78) and Mantle thrust system of the Himalayan front along the Pakistan-Afghanistan border (fig. 7). Quaternary deformation in this domain is driven largely by westward- and northwestward-directed contraction between the Indian and Eurasian plates. This domain is characterized by a series of major southeast-verging thrust fault zones that are generally defined by sets of arcuate fault scarps, which are bounded by southeasttrending linear features that we interpret to be tear faults.

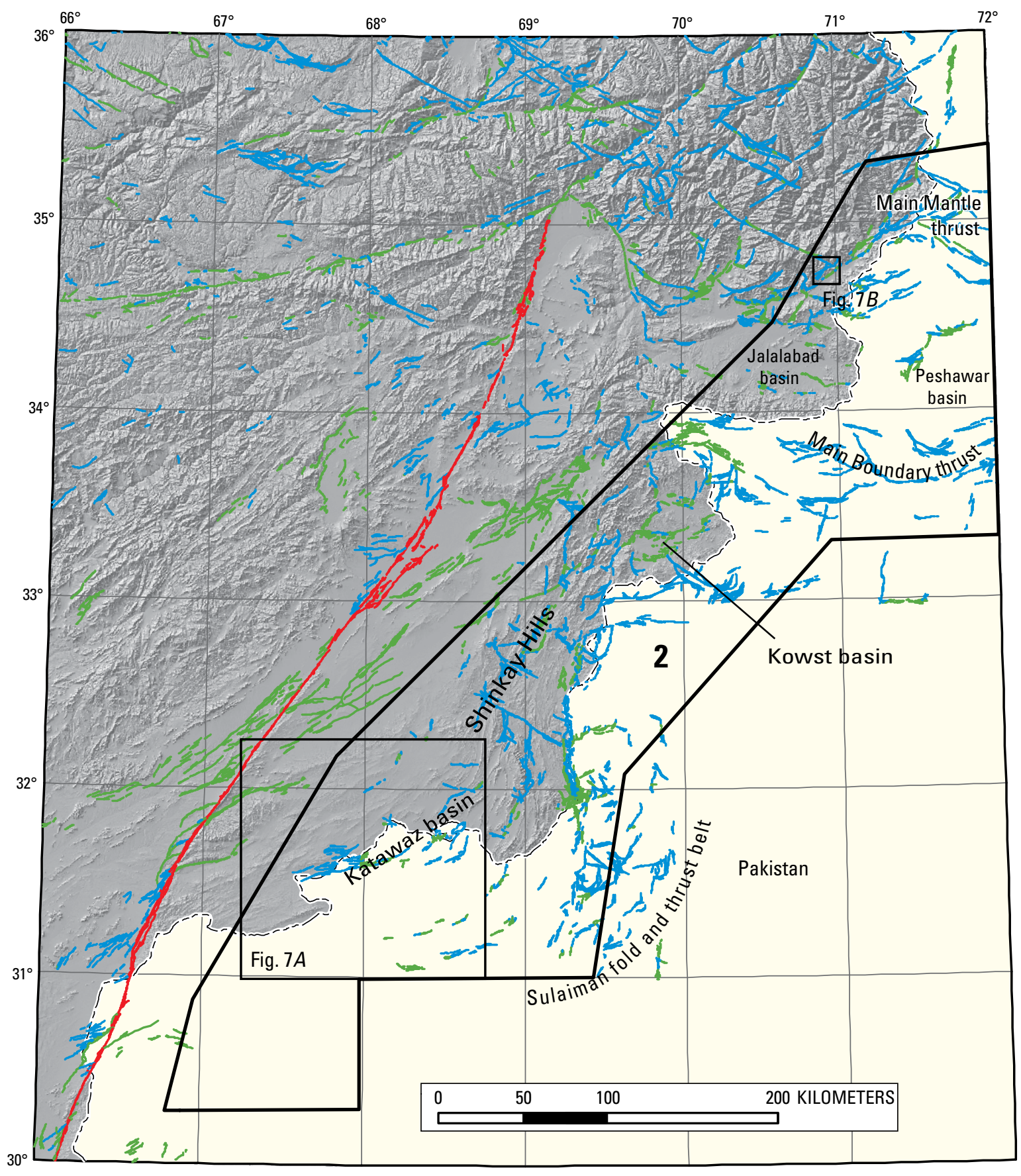

Figure 7. Tectonic domain 2-the Sulaiman fold-and-thrust belt and associated contractional zones outlined in black. Deformation in this domain is driven by west- to northwest-directed contraction related to the collision between the Indian and Eurasian plates. Fault categories are category A, red; category B, green; and category C, blue. 
The southern one-third of Domain 2 is in the Sulaiman fold-and-thrust belt, which is composed of intensely folded and faulted Eocene-Oligocene rocks of the Katawaz Basin suite (Abdullah and Chmyriov, 1977). Bernard and others (2000) calculated that $5-14 \mathrm{~mm} / \mathrm{yr}$ of north-south motion and 3-6 mm/yr of northwest-southeast shortening is accommodated between the Indian and Eurasian continents across this fold-and-thrust belt. Our evidence of Quaternary activity in this region is based on the presence of discontinuous, arcuate, convex-to-the-southeast scarps on basin-fill and playa deposits (pl. 1, no. 90) (fig. 7A). The fault scarps trend both parallel to and across the structural grain of the region. Along the Pakistan-Afghanistan border, near the confluence of the Gumal and Kundar Rivers (pl. 1), we recognized an apparent change in the polarity of thrust faults from northwest-dipping, southeast-verging to southeast-dipping, northwest-verging. In this region, we mapped an approximately $20-\mathrm{km}$-wide zone, where the pattern of surficial faults is complex with various orientations and expressions; this suggests that deformation is driven by wrench-faulting tectonics (pl. 1, no. 89 and 90). Scarps are present on piedmont and valley alluvium and vary from east- and west-facing, arcuate discontinuous scarps to northeast- and northwest-trending lineaments that we interpret to be active thrust and tear faults that have developed as a result of northwest-southeastdirected compression.

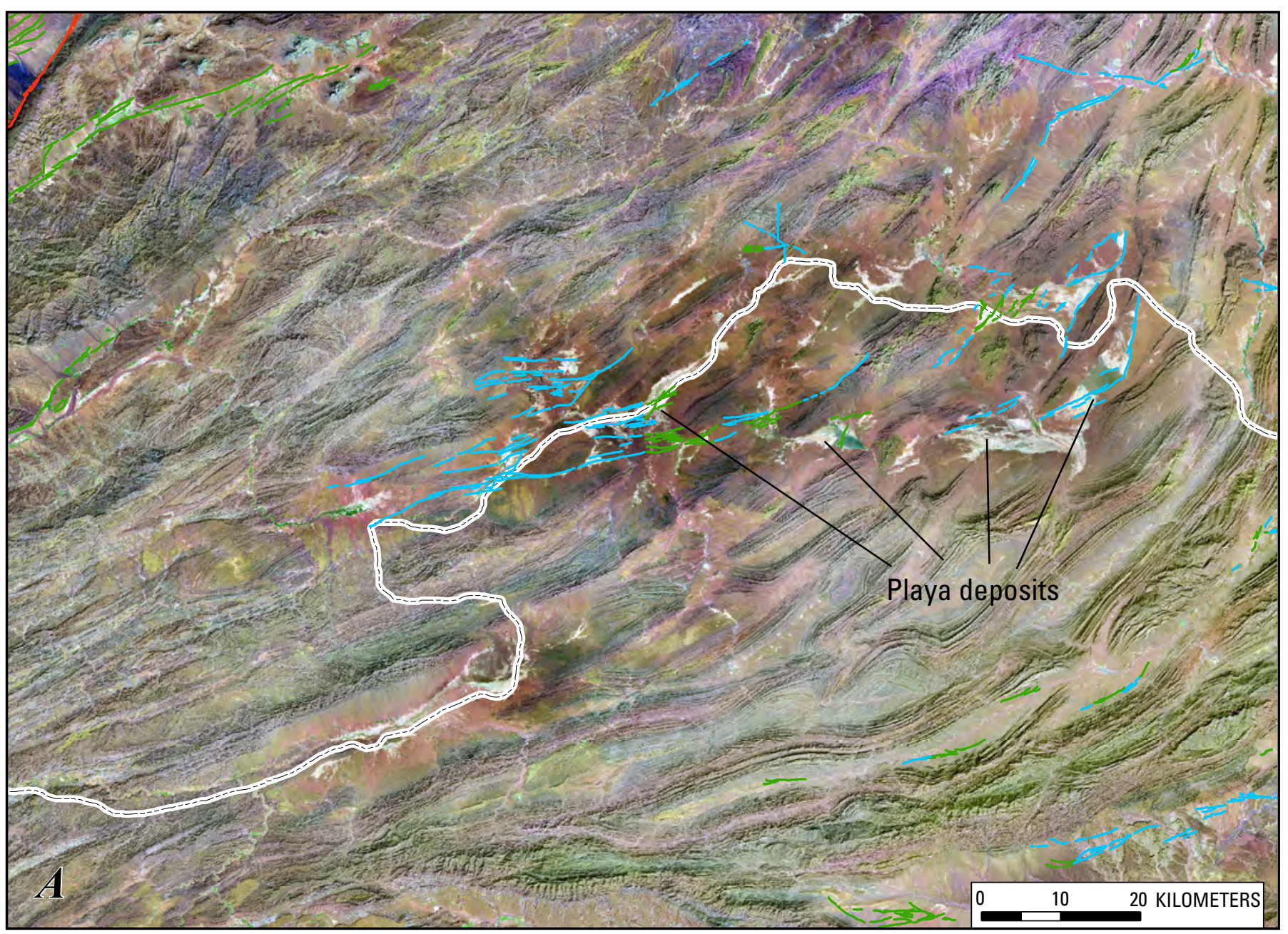

Figure 7A. Landsat image of the Sulaiman fold-and-thrust belt (pl. 1, no. 90) composed of intensely folded Eocene and Oligocene rocks in the Katawaz basin. Dissected and uplifted playa deposits indicate that active thrust faulting is advancing southeastward and uplifting and faulting older basin-fill deposits. Fault categories are category A, red; category B, green; and category $\mathrm{C}$, blue. Image is a panchromatically enhanced Landsat image that merges bands $7+4+1$. White dashed line is border between Afghanistan and Pakistan. See figure 7 for location. 
To the north throughout the generally rugged, mountainous terrain of the Shinkay Hills region (fig. 7), we mapped fault scarps on both sides of several basins (pl. 1, no. 82 and 83). We identified discontinuous, arcuate and linear, north-northeast-trending scarps on piedmont alluvium. The displacements are mainly vertical, dip-slip movements and can be interpreted as either normal or thrust faults within our regional kinematic model. Southeast-verging thrust faults to the north and south of these basins merge with a zone of northwest-trending lineaments that have apparent strike-slip motion (pl. 1, no. 87). The faults bounding these basins could be either a continuation of the thrust faulting to the north and south, or pull-apart basins at stepover zones in the northwesttrending strike-slip fault zones within the region. North of the Shinkay Hills, Quaternary tectonism primarily involves southsoutheast- and southeast-verging thrust faults.

The western margin of the Kowst basin (fig. 7) is defined by a linear range front that has discontinuous, northeast-trending, arcuate scarps along the boundary between the mountain front and the adjacent piedmont (pl. 1, no. 70 and 73). Features in the piedmont alluvium and shutter ridges indicate that deformation along the range front results from sinistral-oblique thrust faulting. We interpret east-northeast-trending, discontinuous, arcuate scarps on basin-fill deposits as evidence that deformation associated with the range front is advancing eastward into the basin. Along the northern margin of the Kowst basin, discontinuous, arcuate scarps on the piedmont define an east-west-trending zone of Quaternary faulting. This region is in the vicinity of the Himalayan Main Boundary thrust and may be its western extension.

From the Kohat Plateau to Parachinar (Pakistan), the Main Boundary thrust (pl. 1, no. 78), Safed Koh fault (no. 74, Plate 1), and numerous associated, subsidiary faults define a network of south-verging thrust faults. McDougall and Hussain (1991) describe out-of-sequence thrust faulting in this region with greater than 50 percent shortening in Tertiary sediments and blind thrust faults having at least twice as much horizontal shortening than that documented at the surface. The Parachinar region is in the Parachinar syntaxis, a region bounded by the Main Boundary thrustSafed Koh fault system on the northeast and the Kowst fault system on the southwest. Quaternary activity along these faults is characterized by discontinuous, arcuate, range front and piedmont scarps on Quaternary deposits. Evidence for Quaternary activity along the generally west-trending, south-stepping Safed Koh and Main Boundary fault systems indicates that the Main Boundary fault consists of an active duplex thrust system with multiple, south-verging imbricate thrust faults. In the Parachinar region, Nakata and others (1991) identified middle Pleistocene alluvial fans that are vertically displaced as much as $20 \mathrm{~m}$, suggesting that active faults are present along all of the Parachinar-Kala Chitta fold belt (pl. 1, no. 71, 75, and 78).

The southern margin of the Jalalabad basin (fig. 7) coincides with a network of west-northwest-trending, discontinuous, arcuate fault scarps on piedmont and valley alluvium (pl. 1, no. 56). To the east, landforms are leftlaterally displaced, and to the west, they are right-laterally displaced. The overall pattern of Quaternary features in the basin indicates that the east and west margins are tear faults associated with south-directed thrust faulting.

We mapped features indicative of southward-directed contraction in the Peshawar basin, where Yeats and Hussain (1989) described four northeast-trending, left-stepping, en echelon pressure ridges that are bounded by late Quaternary thrust faults (pl. 1, no. 77). These faults are characterized by northeast-trending, discontinuous scarps on intra-basin alluvium with no apparent Holocene displacement. The most recent event on these subsidiary faults to the Main Boundary fault system is on the order of $100,000 \mathrm{yr}$. (Yeats and Hussein, 1989).

The northern part of Domain 2 contains fault strands that are associated with the Main Mantle thrust of the Himalayan system and the Konar fault (pl. 1, no. 47, 48, and 52). In this area, we recognized features that define a transition from the dominantly left-lateral faulting of the Chaman-Gardiz fault system to a pattern of south-southeast-verging thrust faulting, which is related to the Main Mantle and Main Boundary fault systems. As determined by Chandra (1978), these observations are supported by thrust-faulting focal mechanisms with nodal planes that are oriented to the northeast. We identified east- to northeast-trending, discontinuous, arcuate scarps along the range-front-alluvium contact and in intrabasin deposits yielding evidence of left-lateral motion on northeast-trending features and right-lateral motion on northwesttrending features.

The northern margin of the Peshawar basin is bounded by a southeast-verging thrust fault system that is probably associated with the Main Mantle thrust. This thrust system is part of the Dargai fault system (pl. 1, no. 55) and is characterized by northeast-trending, discontinuous, arcuate, range-bounding and piedmont scarps. Based on the morphology and stratigraphic position in the landscape, progressively older landforms are offset greater amounts indicating recurrent movement on strands of this fault system.

Along the Konar fault (pl. 1, no. 52), we mapped northeast-trending scarps on piedmont alluvium and near the contact between valley alluvium and range-front colluvium. Old landforms, shutter ridges, and active stream channels all indicate a left-lateral sense of movement on this fault (fig. 7B). We recognized sinistral offsets in young deposits of active alluvial fans, which is evidence of recent surface faulting. Northeastward along the Konar fault, the range-front morphology, shutter ridges, and southeast-facing fault scarps all indicate a progressively greater component of thrust faulting. Farther to the northeast, the Konar fault merges into a north-northeasttrending fault zone (pl. 1, no. 47 and 48) that is associated with discontinuous, arcuate range-bounding scarps on both fan alluvium and at the bedrock-colluvium contact. The sense of slip on this section of the fault appears to be primarily thrust faulting, and recent movement on this thrust front appears to 


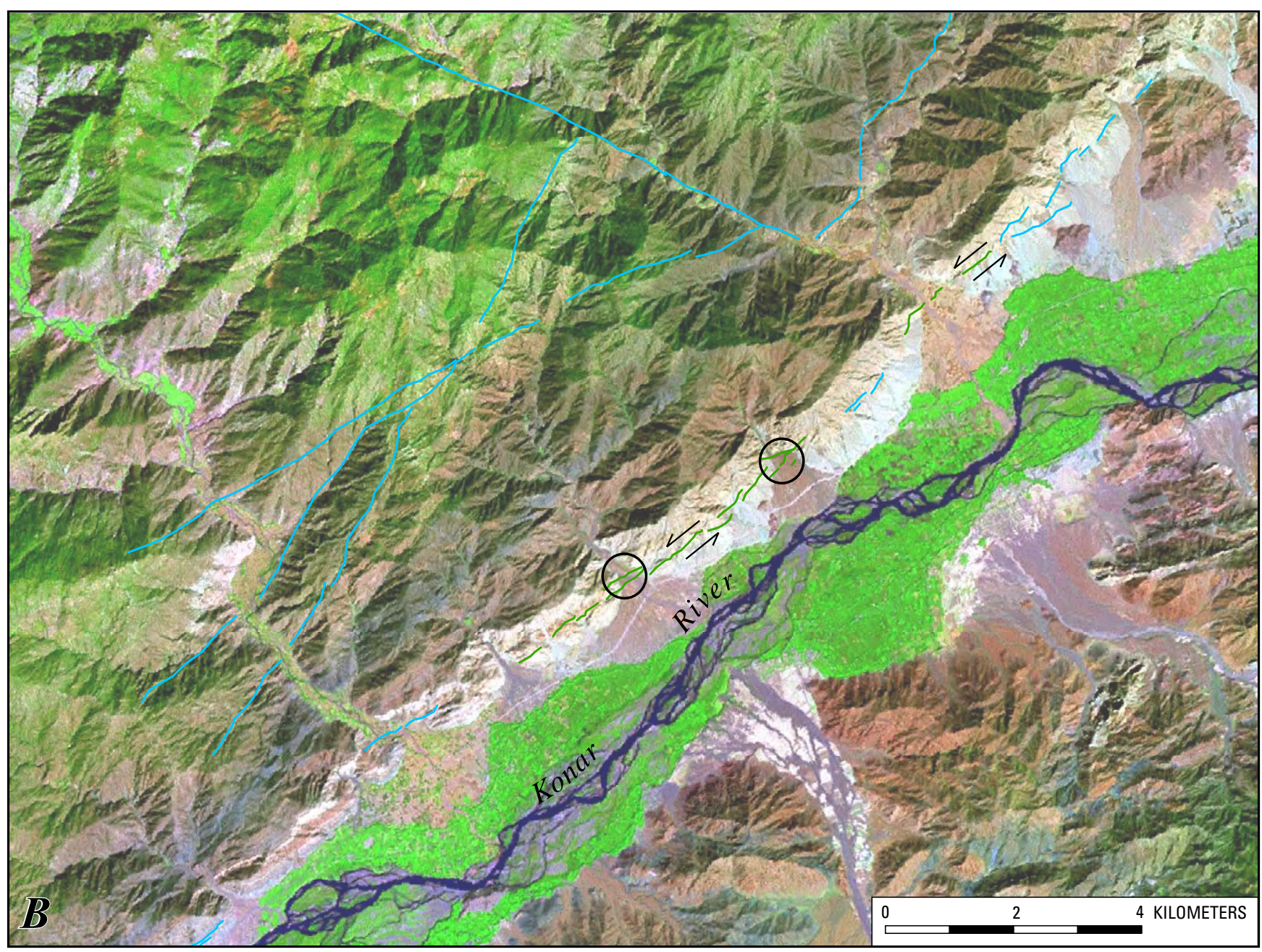

Figure 7B. Landsat image of part of the Konar fault system (pl. 1, no. 52). The range-bounding thrust fault shows evidence of left-lateral offset (indicated by arrows), whereas lineaments in the adjacent mountains are preserved on rapidly eroding bedrock hillslopes, which suggests that they are probably active and involve multiple fault strands. Fault categories are category B, green; and category C, blue. Image is a panchromatically enhanced Landsat image that merges bands $7+4+1$. See figure 7 for location.

control the course of the Konar River. This fault system continues northeastward into the Chitral region of Pakistan and might merge with the Main Karakoram and Tirich Mir fault systems.

\section{Domain 3 - Hindu Kush-Pamir Intermontane Region}

Domain 3 covers northeastern Afghanistan and includes the provinces of Badakhshan, Nuristan, and Takhar (fig. 8). This is a region of transpression and contains a diverse array of fault types and orientations as previously compiled by Abdullah and Chmyriov (1977). These faults have a generally north- to northeast-trending, pre-formed structural grain. In contrast, the general pattern of Quaternary faults trends northwest and cuts across this antecedent structural grain. The young, northwest-trending features appear to be strike-slip fault zones that are expressed as lineaments across the Hindu Kush-Pamir region. The pronounced difference between the older northeast-trending structural grain and the younger north- to northwest-trending features suggests that a change in deformational style and mechanics has occurred; from an initial phase of contraction, to a more recent phase of shearing and northwest-directed crustal extrusion along strike-slip fault zones. Our mapping supports the observations of Verma and others (1980) that northwest-trending seismicity lineaments extend from the Main Boundary thrust of the Kashmir Himalayas to the Amu Darya River in north-central Afghanistan and southern Uzbekistan. They also found that thrust and strike-slip faults are equally prevalent in this tectonic domain. We found some evidence of active northeast-trending thrust faults indicating continuing contemporary contraction; but, 


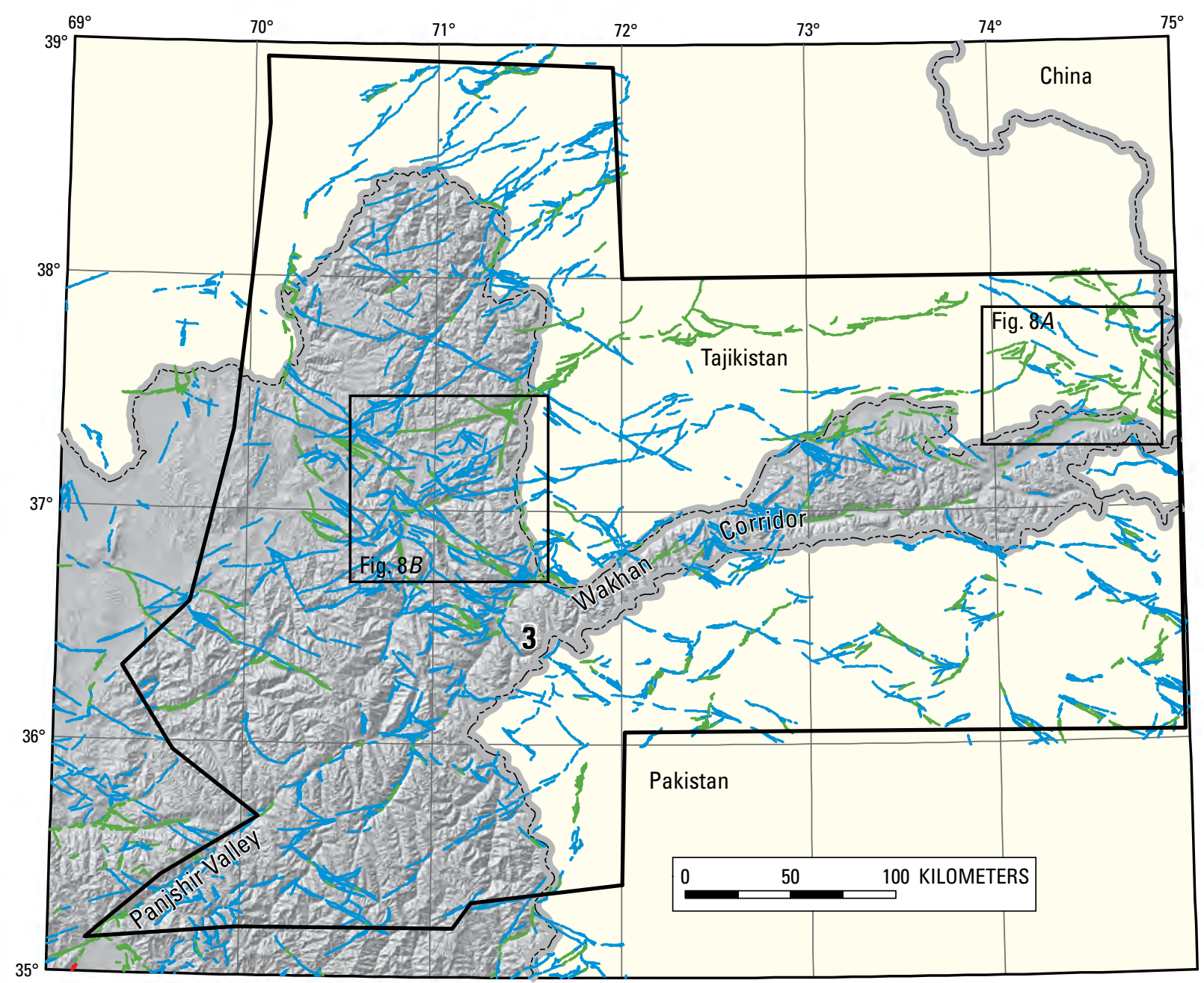

Figure 8. Tectonic Domain 3-Northeastern Afghanistan-Hindu Kush region outlined in black. The northeast-trending structures in this region appear to be part of an older structural grain, and the young structures are northwest-trending strike-slip faults. Fault categories are category A, red; category B, green; and category $\mathrm{C}$, blue.

in many places, these thrust faults appear to be offset by northwest-trending strike-slip faults.

These northwest-trending lineaments typically are characterized by linear, nearly continuous bedrock escarpments in high alpine terrain. Locally, these faults control drainages and form shutter ridges. The deflection of rivers and stream channels is further evidence of recent fault activity. Minor thrust and normal faults are present near stepovers in these zones. Landforms and other geomorphic evidence indicate that most of these zones have a right-lateral sense of movement.

The Panjshir Valley (fig. 8) is bounded on the north by active oblique-thrust faulting. We mapped northeast-trending, discontinuous, arcuate scarps at the range front, on alluvial fans and landslide deposits, and on other Quaternary deposits adjacent to the precipitous mountain front (pl. 1, no. 43). Shutter ridges and deflected streams indicate right-lateral displacement. Active thrust faults are mainly southeast-verging and locally merge into the northwest-trending strike-slip fault zones. We mapped minor thrust faults to the north, where they are characterized by arcuate, discontinuous scarps on bedrock and where Quaternary faulting is indeterminate. Structural control of the Panjshir Valley is apparent from southwesttrending fluvial systems that flow along the thrust front.

At the northeastern corner of the Wakhan Corridor along the Afghanistan-Tajikistan border, the interaction between southeast-verging thrust faults and northwest-trending strike-slip fault zones creates a complex network of fault types and orientations (fig. 8A). The northeast-trending thrust systems coincide with range fronts and are associated with arcuate, discontinuous scarps. Locally, they systematically deflect streams which are evidence of youthful activity. The northwest-trending strike-slip zones coincide with linear, continuous scarps that trend parallel to major range fronts. The stream deflections and shutter ridges indicate a right-lateral sense of movement. 
In the northeast corner of Domain 3 along the headwaters of the Murghob River (fig. 8A) (pl. 1, no. 1), we identified a prominent zone of normal, basin-margin faults at a right step in this right-lateral shear zone. The normal faults are marked by continuous, sub-linear, east- and west-facing scarps on alluvial fans at the mouths of major canyons along north-northwest-trending range fronts. The right-lateral shear zone creating these normal faults is possibly related to the major right-lateral Karakoram fault, located approximately $50 \mathrm{~km}$ to the east, as synthetic conjugate faults. The geomorphic expression of these faults is similar to that of the Karakoram fault, which has a slip rate of 3-4 mm/yr (Brown and others, 2002), so we infer that these faults have a generally similar slip rate (category $\mathrm{B}$ ).
In north-central Badakhshan (fig. 8A), the Quaternary deformation is partitioned between southeast-verging thrust faults and conjugate shear zones; the orientation of these features indicates that this deformation is being driven by compression that is oriented in a northwest-southeast direction (fig. 8b). Thrust faults and both left-lateral and right-lateral fault systems show evidence of probable recent activity, which indicates that there is a complex interplay between faults in this transpressional region. Strike-slip faults are marked by both northwest- and north-northeast-trending lineaments that have continuous, linear scarps crossing bedrock terrain and trending parallel to major valleys. Along northwest-trending lineaments, shutter ridges indicate a right-lateral sense of displacement. The thrust faults trend

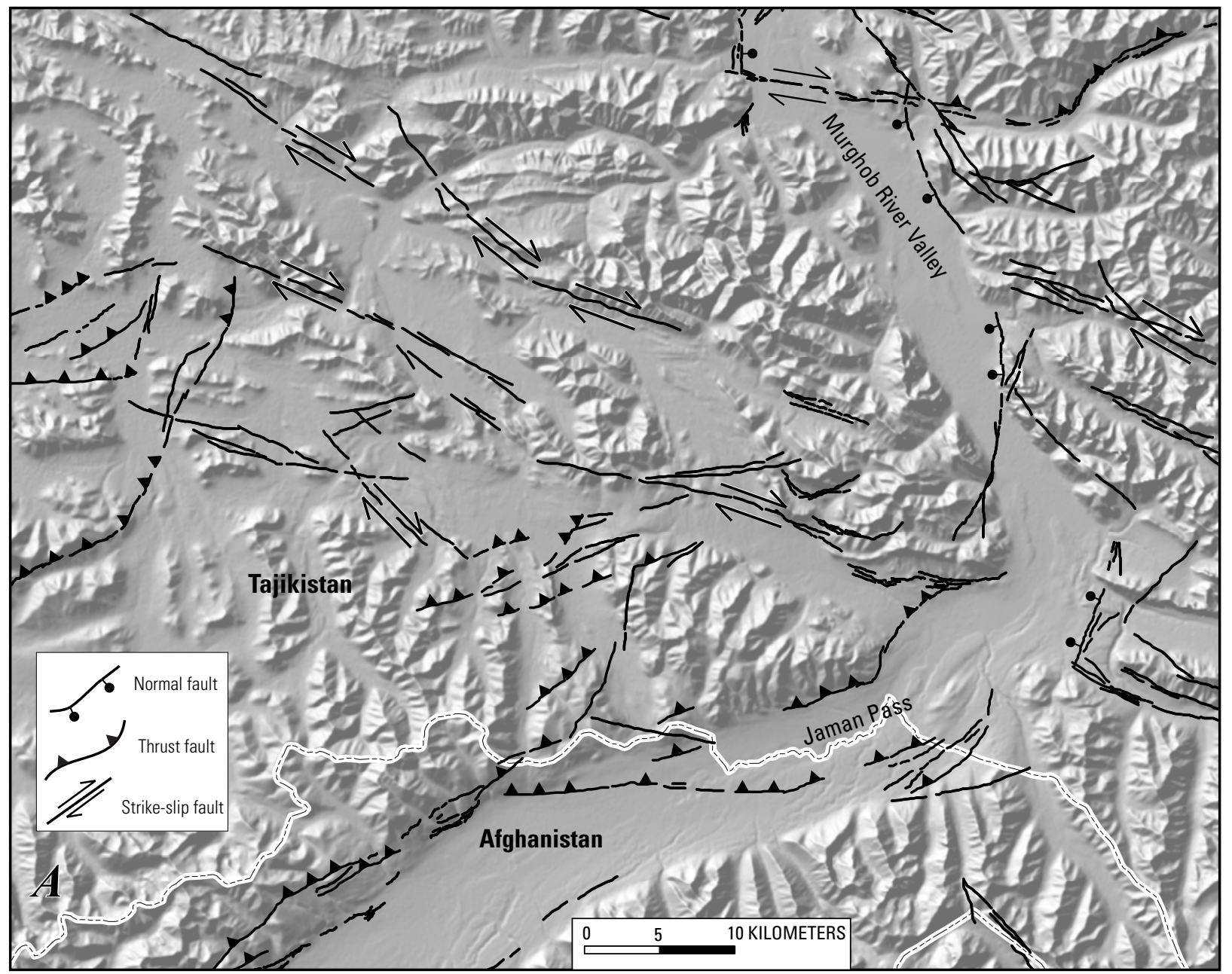

Figure 8A. Map of features associated with active tectonics in northeastern Afghanistan and the Jaman PassMurghob River region of Tajikistan (pl. 1, no. 1 and 3). Features thought to have strike-slip movement have arrows showing directions of movement. Thrust faults have teeth on upthrown side. Normal faults in the Murghob River Valley have a bar and ball on the downthrown side. These features are predominantly category B structures and have inferred slip rates of 1-10 mm/yr. Base map is from SRTM (Shuttle Radar Topographic Mission) data. White dashed line is boundary between Afghanistan and Tajikistan. See figure 8 for location. 
northeastward and have discontinuous to continuous, arcuate range-bounding and intermontane scarps.

In the Shiwa Lake region (fig. 8b), a set of active conjugate strike-slip faults offsets multiple generations of landslides (fig. 9). The distinctly different morphology of the landslides indicates that they are significantly different in age. Large earthquakes commonly produce large landslides in mountainous terrain (see Alford and Schuster, 2000; Baum and others, 2001; Harp and Crone, 2006), so considering the size and apparent time intervals between these slope-failure events, we consider the landslides to be of probable seismogenic origin.

At the northern border of Afghanistan, the north-trending, left-lateral Darvaz fault (pl. 1, no. 21) is truncated by northwest-trending, strike-slip fault zones. North of the border in Tajikistan, the Darvaz fault shows evidence of Quaternary movement; the fault is associated with continuous, north- to northeast-trending, range-bounding fault scarps on piedmont

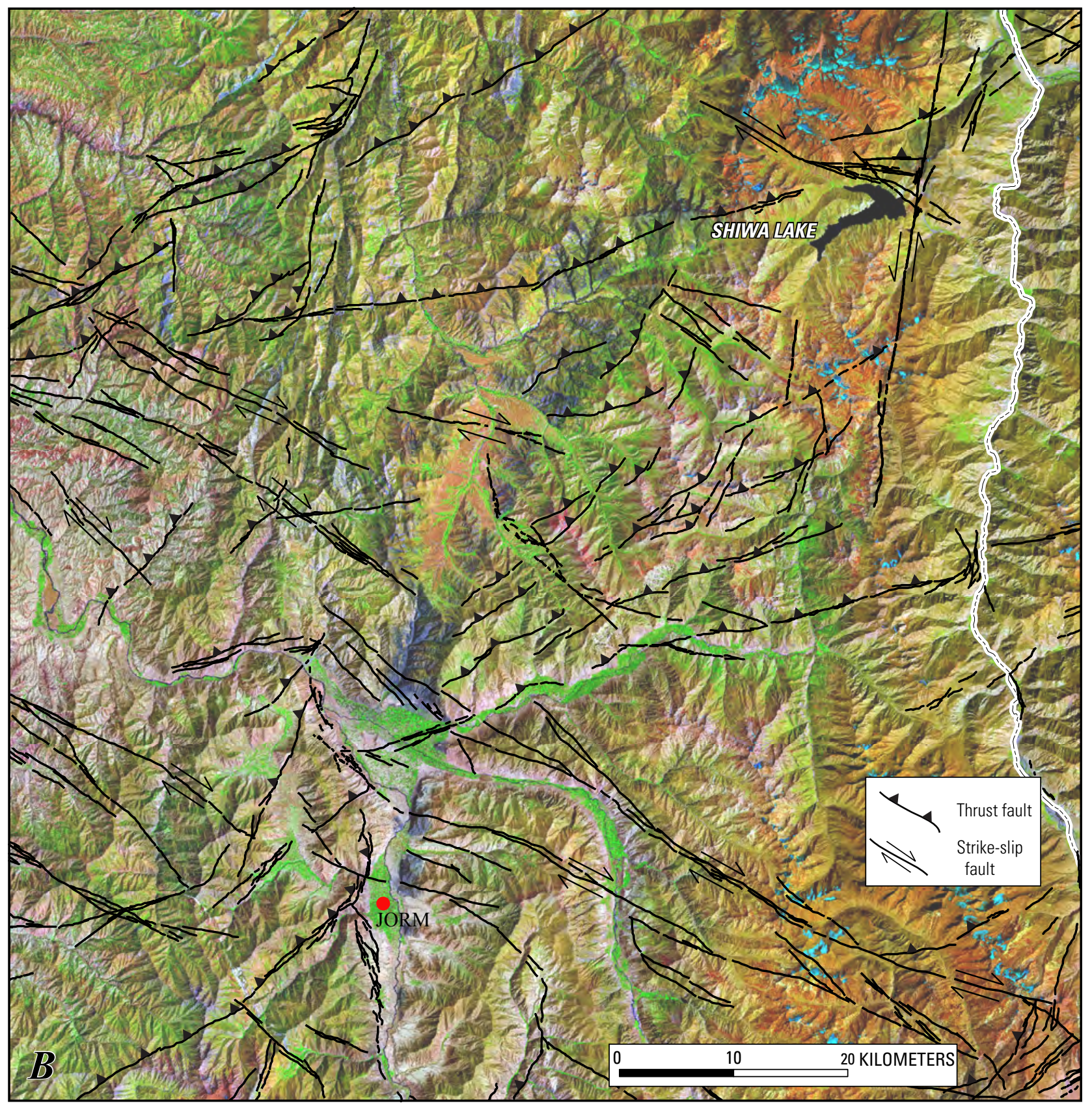

Figure 8B. Map of features associated with active tectonics, central Badakhshan. The Quaternary deformation in this region appears to be partitioned between southeast-directed thrust faults and and northwest-trending right-lateral strike-slip faults. The faults are predominantly classified as category $\mathrm{C}$ faults (pl. 1, no. 23 and 25). Image is a panchromatically enhanced Landsat image that merges bands $7+4+1$. See figure 8 for location. 
$71^{\circ} 24^{\prime}$

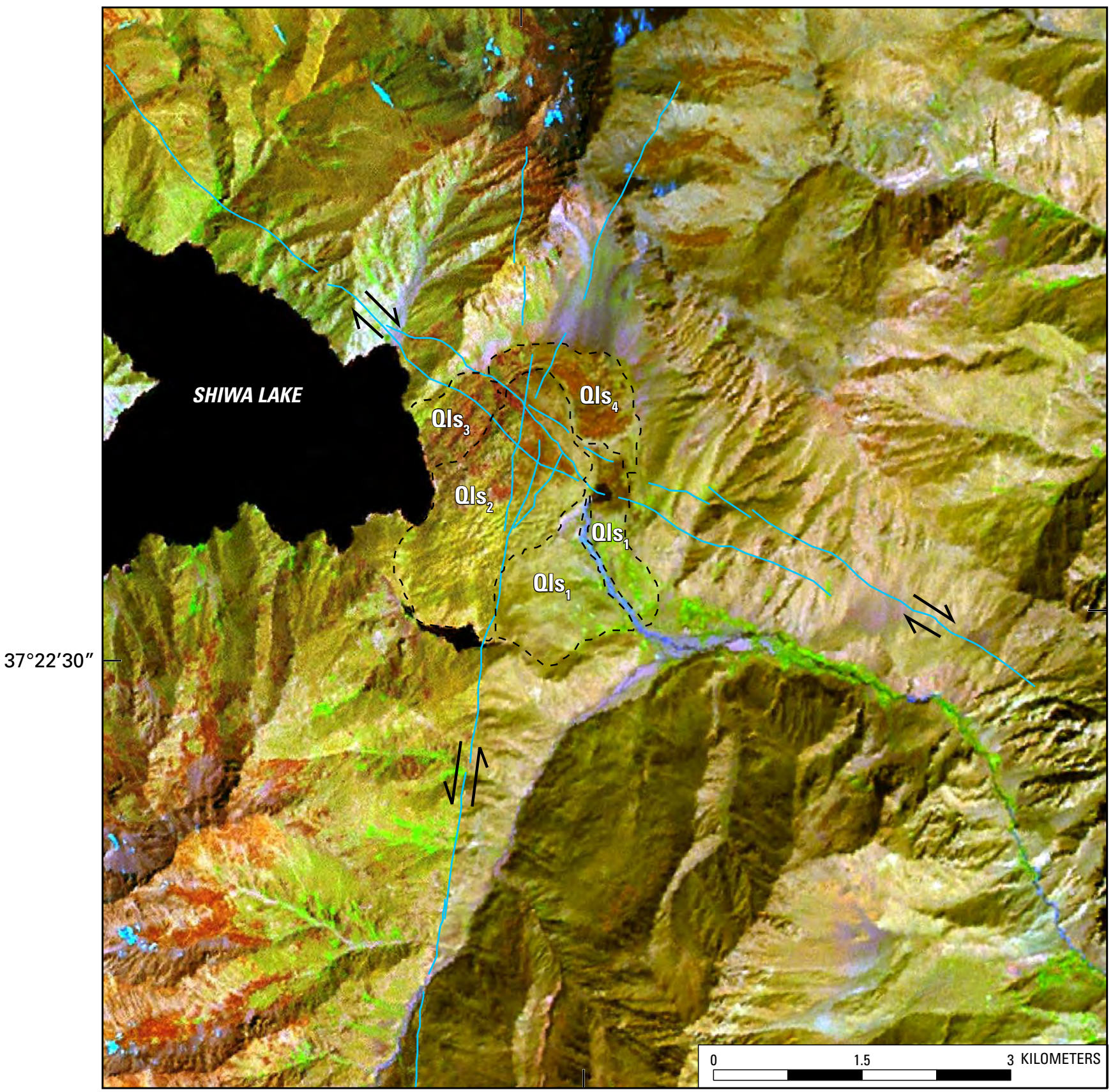

Figure 9. Surface expression of category $\mathrm{C}$ faults east of Shiwa Lake in the Hindu Kush, northeastern Afghanistan (pl. 1, no. 23). Shiwa Lake formed because several generations of landslides have dammed the valley. Landslides range in age from oldest $\left(\mathrm{Qls}_{1}\right)$ to youngest $\left(\mathrm{Qls}_{4}\right)$. These landslides are likely caused by earthquakes (that is, seismogenic landslides). The faults (blue lines with black arrows showing directions of movement) mainly cross bedrock slopes, but their expression on the surface of the landslides Qls ${ }_{1}, \mathrm{Qls}_{2}$, and Qls $\mathrm{s}_{3}$ indicates that recent movement on the faults is younger than the landslides and that the faults are active. The amount of fault displacement on the landslides could not be measured because of limited resolution of the imagery. Image is a panchromatically enhanced Landsat image that merges bands $7+4+1$. 
alluvium. Normal faults are present at stepovers and jogs along the fault. Deflections of modern, active stream channels indicate a left-lateral sense of displacement.

Previously mapped major faults in the region are northtrending structures, and include the Central Badakhshan (pl. 1, no. 20), Henjvan (pl. 1, no. 18), and Darvaz faults. However, our mapping suggests that these fault zones may actually be composite structures that are comprised of segments of northwest- and north-northeast-trending, strike slip faults and segments of southeast-verging thrust faults. Additional studies using higher-resolution imagery and field investigations are needed to more accurately characterize these faults.

\section{Domain 4 - The Hari Rud-Northern Afghan Platform System}

Domain 4 encompasses a region that is interpretted as being deformed by primarily transtensional forces in the Trans-Himalayan orogenic belt (fig. 10). We speculate that large east-west-trending, right-lateral, strike-slip fault zones (for example, the Hari Rud, and Andarab fault systems) (pl. 1) are key structures that have played an important role in the westward-extrusion of the Northern Afghan Platform.

The Hari Rud (also known as the Herat) fault system (pl. 1, no. 60,117, 123, and 124) is a major continental-scale suture that coincides with the boundary between the relatively stable, mildly deformed Eurasian (Laurasia) continent to the north and the extensively deformed, accreted terrains to the south (Tapponnier and others, 1981). The fault has been a major tectonic boundary since early Mesozoic time and may have originated as a north-dipping suture. In Tertiary time, motion on the fault was mainly dextral slip. The presence of elongate fault basins filled with Oligocene and Miocene sediment suggests that strike-slip motion was most active during this time (Tapponnier and others, 1981). Limited field studies suggest that at least the eastern part of the Hari Rud fault has not been highly active since Miocene time (Tapponnier and others, 1981), but locally small landforms and other geomorphic features appear to be offset, indicating that some Quaternary movement/motion may have occurred on the fault.

The Hari Rud fault system extends approximately $600 \mathrm{~km}$ in a generally east-west direction from the northern end of the Paghman fault (pl. 1) on the east to beyond the city of Herat on the west (pl. 1, fig. 1). For the purposes of our mapping, we have subdivided the Hari Rud fault system into four sections, based on broad differences in the system's orientation and its general expression on the landscape. In addition, we apply the name Hari Rud fault system only to those features that trend approximately east-west and extend westward from the junction of the Paghman and Panjshir faults (pl. 1), as described by Wheeler and others (2005). This differs from the longer network of faults that Wellman (1965) described and named the Hari Rud fault system.

The eastern (pl. 1, no. 60) and central sections (pl. 1, no. 117) of the Hari Rud fault system are mainly expressed in the landscape as linear valleys and drainage networks, or by aligned escarpments on bedrock. The fault system controls the course of major drainages and commonly is composed of

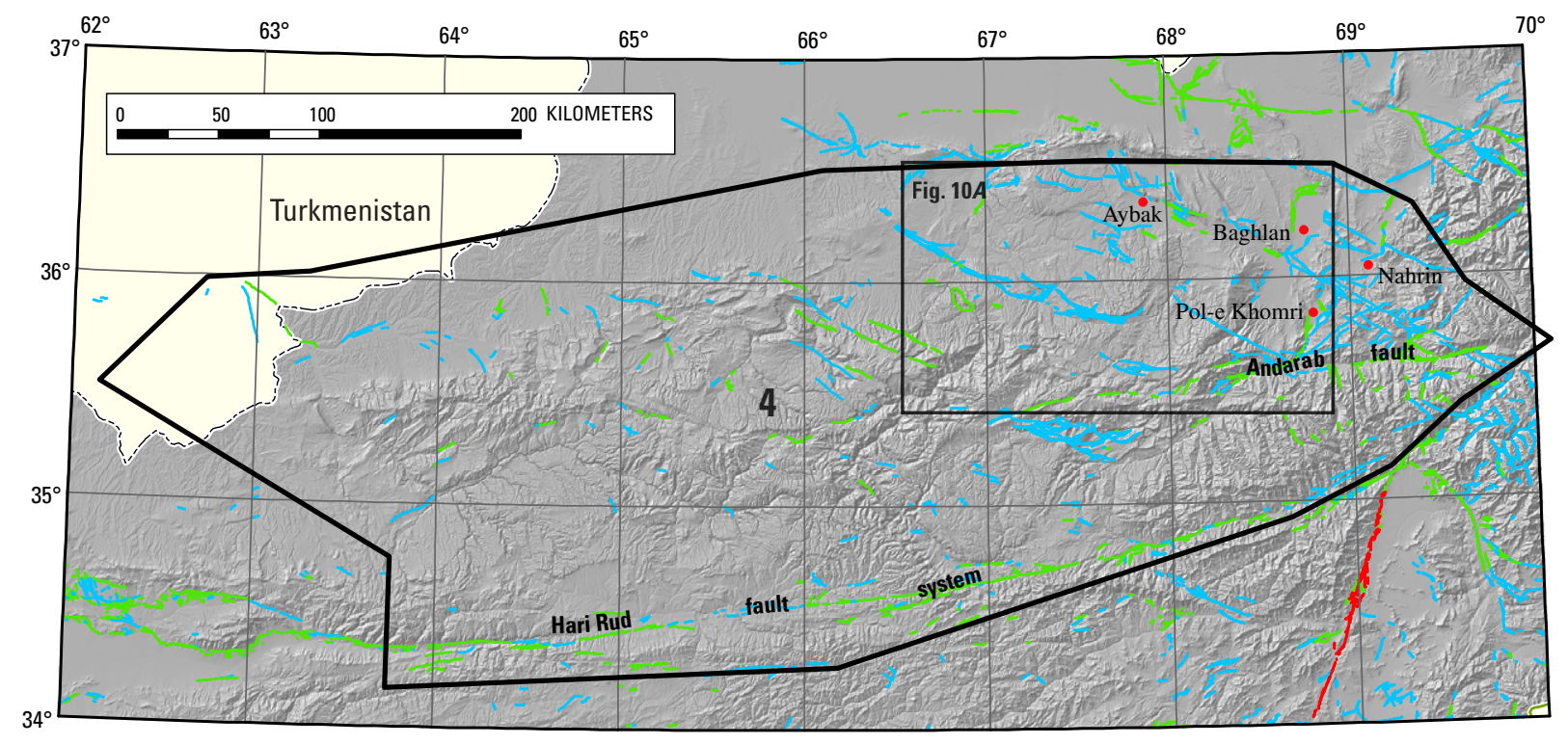

Figure 10. Tectonic domain 4-Hari Rud-Northern Afghan platform system outlined in black. The Andarab and Hari Rud fault systems in this domain probably play an important role in the westward extrusion of this region as a result of the Indian and Eurasian plate collision. In March 2002, a M 6.1 earthquake in Nahrin caused more than 1,000 fatalities and widespread damage. Fault categories are category A, red; category B, green; and category C, blue. 
several parallel to subparallel strands. The main distinction between the eastern and central sections is their overall orientation; the eastern section trends east-northeast, whereas the central section trends east-west.

About $100 \mathrm{~km}$ east of the city of Herat, the valley of the Hari Rud River widens and is bounded on the north by prominent, south-facing range fronts. We define the western section of the Hari Rud fault system (pl. 1, no. 123 and 124) as beginning at this widening point and extending westward along the mountain front to an area about $80 \mathrm{~km}$ west of Herat. Features along the western section generally coincide with these range fronts or are present on Pleistocene alluvial fans that extend into the valley from the mountains. Because most of these features are associated with the margins of mountain ranges, their primary sense of displacement is likely to be vertical, which distinguishes them from the features we assign to the central and eastern sections.

Near the boundary between the central and western sections, a prominent set of lineaments extends northwestward out of the Hari Rud River Valley, and continues to the northwest into the region of alluvial basins and ranges north of Herat. Here, we mapped a network of variably oriented features in basin fill and along range fronts that we combine into the northwestern section of the Hari Rud fault system (pl. 1, no. 123). We suspect that many of these features are formed by oblique-slip faults. The range-front features separate bedrock in the ranges from Quaternary deposits in the valleys; locally, the range fronts have distinct faceted spurs. In this section, we also include features in extreme western Afghanistan and adjacent eastern Iran to the northwest, that bound isolated bedrock ridges which are surrounded by broad, alluvium-filled valleys.

The Andarab fault (pl. 1, no. 41) coincides with an approximately $150-\mathrm{km}$-long, east-west-trending valley north of the intersection between the Paghman and Hari Rud faults (pl. 1, no. 59, 60, 117, 123, and 124). In the high valley of Darya ye Wulma, Tapponnier and others (1976) observed evidence of young movement on the fault along several kilometers of the trace. The eastern section is confined to a zone that is less than $2 \mathrm{~km}$ wide, and is characterized by sub-linear, continuous scarps on middle to late Pleistocene alluvium and on bedrock surfaces. Shutter ridges and deflected streams indicate a right-lateral sense of displacement. Wellman (1965) describes ridges that have as much as $25 \mathrm{~m}$ of dextral displacement.

Northwest-trending fault zones terminate the eastern limit of the Andarab fault (pl. 1, no. 40 and 110). Along the central section of the fault, intra-valley fault scarps are less continuous than to the east, however, the fault could be concealed beneath a major river course in this area. The western section of the fault zone expands in width to as much as $10 \mathrm{~km}$ and contains multiple strands. Northwest-trending, strike-slip fault zones and northnortheast-trending thrust faults diverge from the western end of the Andarab Valley. Scarps are present on valley alluvium and are more continuous than along the central section.

Northeast-trending thrust faults that bound the Pol-e Khomri basin (pl. 1, no. 39) appear to be related to left steps in a set of northwest-trending, right-lateral, strike-slip fault zones. Farther to the northwest, the Kondoz River flows through two north-trending extensional basins. We mapped north-northeast-trending, discontinuous, linear features along the western side of the southern basin, and we interpret the linear escarpment where we mapped these features to be a fluvially-trimmed fault line scarp that may have Quaternary displacement (pl. 1, no. 34). In the Baghlan basin, we mapped north- to northeast-trending, continuous features along the western and southeastern margins (pl. 1, no. 34). We suspect that westward tilting of the basin in Quaternary time has resulted in fluvial trimming of the western escarpment, but that the escarpment is probably fault controlled. At the northern margin of the basin, the Kondoz River turns abruptly to the northeast, a change in direction that we infer is probably controlled by recent fault activity. Along this major bend, we mapped northeast-trending, discontinuous scarps that have a down-to-the-south sense of displacement. To the east near the town of Nahrin, focal mechanisms of historical earthquakes indicate that east-west contraction is occurring on steeply-dipping thrust faults, one of which produced the destructive March 25, 2002, M 6.1 Nahrin, Afghanistan earthquake (Yeats and Madden, 2003). A linear, north-trending range front bounds the eastern side of the valley where we mapped possible scarps and lineaments in the range, but not along the range front (pl. 1, no. 36). Yeats and Madden (2003) did not report any surface rupture or obvious deformation along the range front from the 2002 event. The absence of surface rupture along the range front could be related to the moderate magnitude of the earthquake; that is, it was not large enough to generate surface rupture, or it could indicate that the range-front fault is not active and that active thrust faulting may be occurring in the range. Detailed field studies are needed to determine if this range-front fault is active.

To the northwest in the Aybak region (fig. 10A), we identified pressure ridges that have formed at a left step in this dextral-shear fault system (pl. 1, no. 33). Discontinuous fault scarps trend north to northwest along the range front and are arcuate on range-front alluvium and colluvium. These features appear to be dominantly dip-slip thrust faults. We interpret continuous, east-west-trending, linear features in the area to be tear faults that link these thrust faults. Displaced old alluvial deposits and pressure ridges indicate a dextral sense of motion on the tear faults.

In the central part of Domain 4, we identified northwesttrending, dextral-slip faults that we infer to be the product of wrench faulting between the Hari Rud (pl. 1, no. 60, 117, 123, and 124), Andarab (pl. 1, no. 41), and Alburz-Marmul (pl. 1 , no. 108) fault zones. These northwest-trending faults are defined by linear, continuous scarps and lineaments in uplands that are underlain by deeply dissected bedrock that has little or no Quaternary deposits (pl. 1, no. 35, 38, 40, and 109-111). To the southeast, these lineaments trend into features that we interpret to be south-southeast-verging thrust faults that are expressed as arcuate, discontinuous scarps on steep bedrock and colluvial surfaces. As we noted elsewhere, these thrust faults coincide with left steps in the northwest-trending dextral shear zones that characterize this domain. 


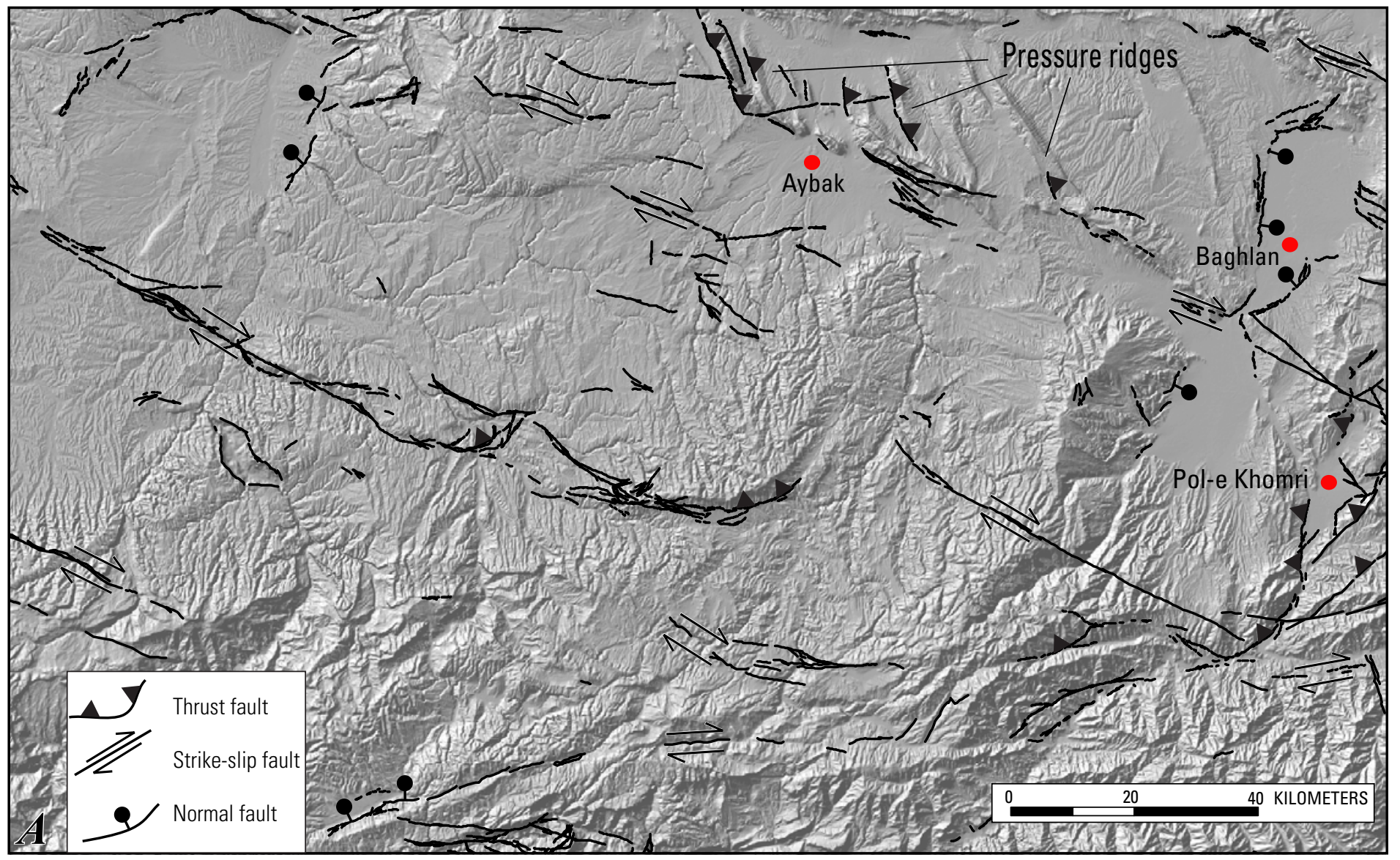

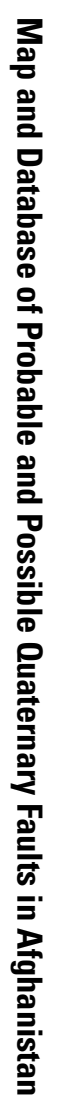

Figure 10A. Features in the Northern Afghan platform that are probably and possibly active, and that play a role in the area's tectonics. A network of northwest-trending, right-lateral strike-slip faults appear to the main features in this area. Thrust faults develop where there are left steps in these strike-slip faults. Base map is from SRTM (Shuttle Radar Topographic Mission) data. See figure 10 for location. 


\section{Domain 5 - The Tajik Basin and Alburz-Marmul Fault System}

This domain covers much of northern Afghanistan (fig. 5) and extends northward into adjacent parts of southern Turkmenistan, Uzbekistan, and Tajikistan. In Afghanistan, most of this region is a vast alluvial plain that is mantled by thick loess deposits and paleo-dune fields. The Amu Darya River defines the northern boundary of Afghanistan in this area (fig. 11), and major river meanders coincide with places where we interpret evidence of Quaternary faulting. Several reaches of the river appear to be incised into newly formed folds. Northward aggradation and progradation of this region is primarily controlled by uplift along the Alburz-Marmul fault system (pl. 1, no. 108). The eastern half of this region shows evidence of a complex interaction between east- and west-verging thrust faults that have formed pressure ridges in sediments as young as early Pleistocene (Abdullah and Chmyriov, 1977). We mapped southeast-verging and west-northwest-verging thrusts that have formed a syntaxial basin in this region (fig. 11) (pl. 1, no. 32, 107, and 108). Our interpretation of active thrust faulting producing a syntaxial basin is consistent with the seismological evidence described by Abers and others (1988), who showed that focal mechanisms and earthquake depths suggest the Tajik basin is actively closing rather than being displaced and transported to the west.

In the eastern half of Domain 5, north-northwest-trending pressure ridges have formed in the western part of the Kondoz basin. The east and west sides of some ridges are marked by discontinuous, arcuate scarps. East-west-trending, continuous, linear scarps link several pressure ridges, interpreted as active tear faults. West of Kondoz, we interpreted active thrust faulting on both east- and west-dipping thrust faults, further indicating active contraction in the region.
The Alburz-Marmul fault system (pl. 1, no. 108) bounds an east-west-trending ridge that is approximately $220 \mathrm{~km}$ long and is composed of Cretaceous sedimentary rocks and Miocene conglomerates, all of which dip steeply to the north. Babayev (1983) reported uplift rates of $21-38 \mathrm{~mm} / \mathrm{yr}$ on the fault system based on measurements of tilted Quaternary terraces. This evidence of contemporary deformation is consistent with our mapping of discontinuous, arcuate features that we interpret to be fault scarps along the northern margin of this ridge. In the vicinity of Balkh, which is northwest of Mazar-e Sharif, a large alluvial-fan complex is filling the basin in front of an active fault-propagation fold (Fig. 11A); we interpret this as evidence of on-going deformation and fold growth. We mapped discontinuous, arcuate scarps on young fan deposits; locally, we identified even younger salt marsh deposits that are ponded against our mapped scarps. At the western end of the Alburz-Marmul fault system, a northwesttrending lineament extends into the basin northwest of Sherberghan; the lineament is characterized by linear, continuous scarps on an upland bedrock surface.

North of the Alburz-Marmul fault system, the geomorphic features suggest that northeast-trending thrust faults are deforming the area and that the dip direction of these faults changes between southeast- and northwest-dipping (Fig. 11A). The features that we interpret to be thrust faults are marked by discontinuous, arcuate scarps on Quaternary age basin-fill deposits. The Amu Darya River has incised into one of these features which we interpret to be a fault-controlled pressure ridge. These intra-basin scarps have the same trend as northeast-striking, southeast-verging thrust faults that have been mapped to the northeast in Tajikistan (Leith and Alvarez, 1985). North of the Amu Darya River, the valleys of active tributary drainages are aligned parallel to the frontal thrust faults suggesting recent fault activity.

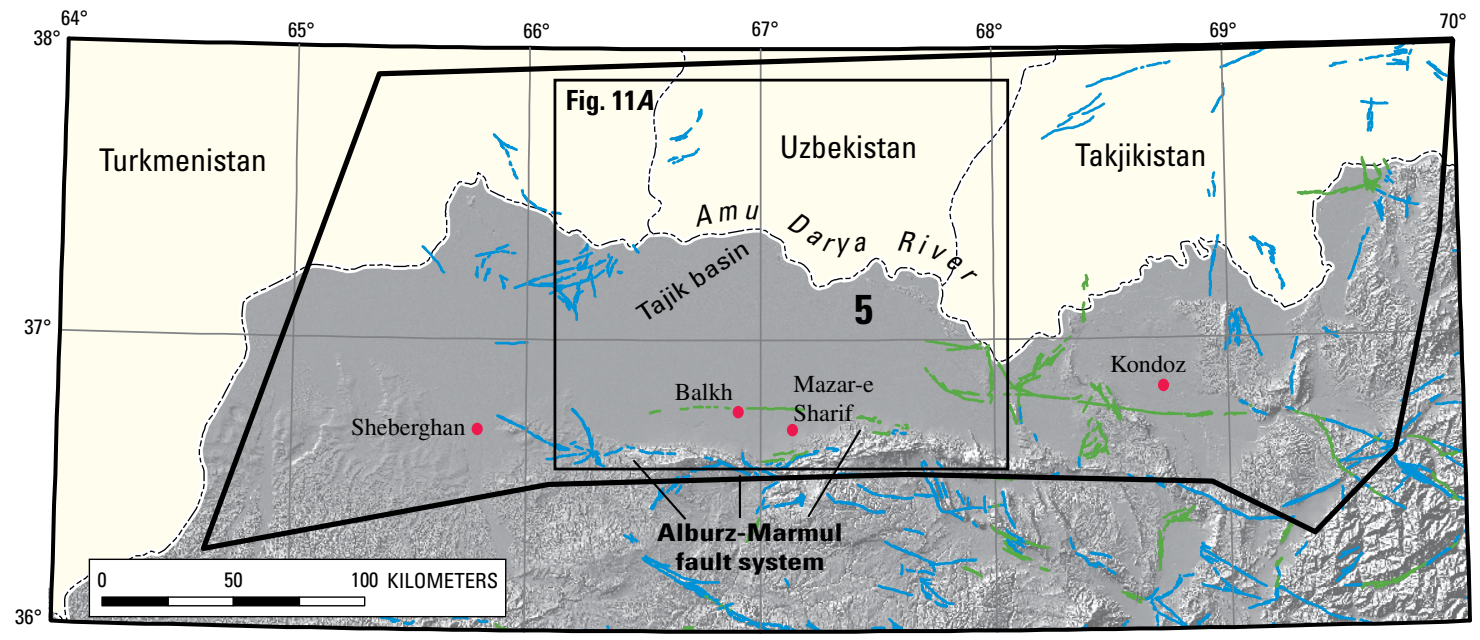

Figure 11. Tectonic domain 5-Tajik basin and Alburz-Marmul fault system outlined in black. The Amu Darya River is the northern boundary of Afghanistan in this area and major meanders in the river coincide with areas that show evidence of Quaternary faulting. Fault categories are category B, green; and category $\mathrm{C}$, blue. 


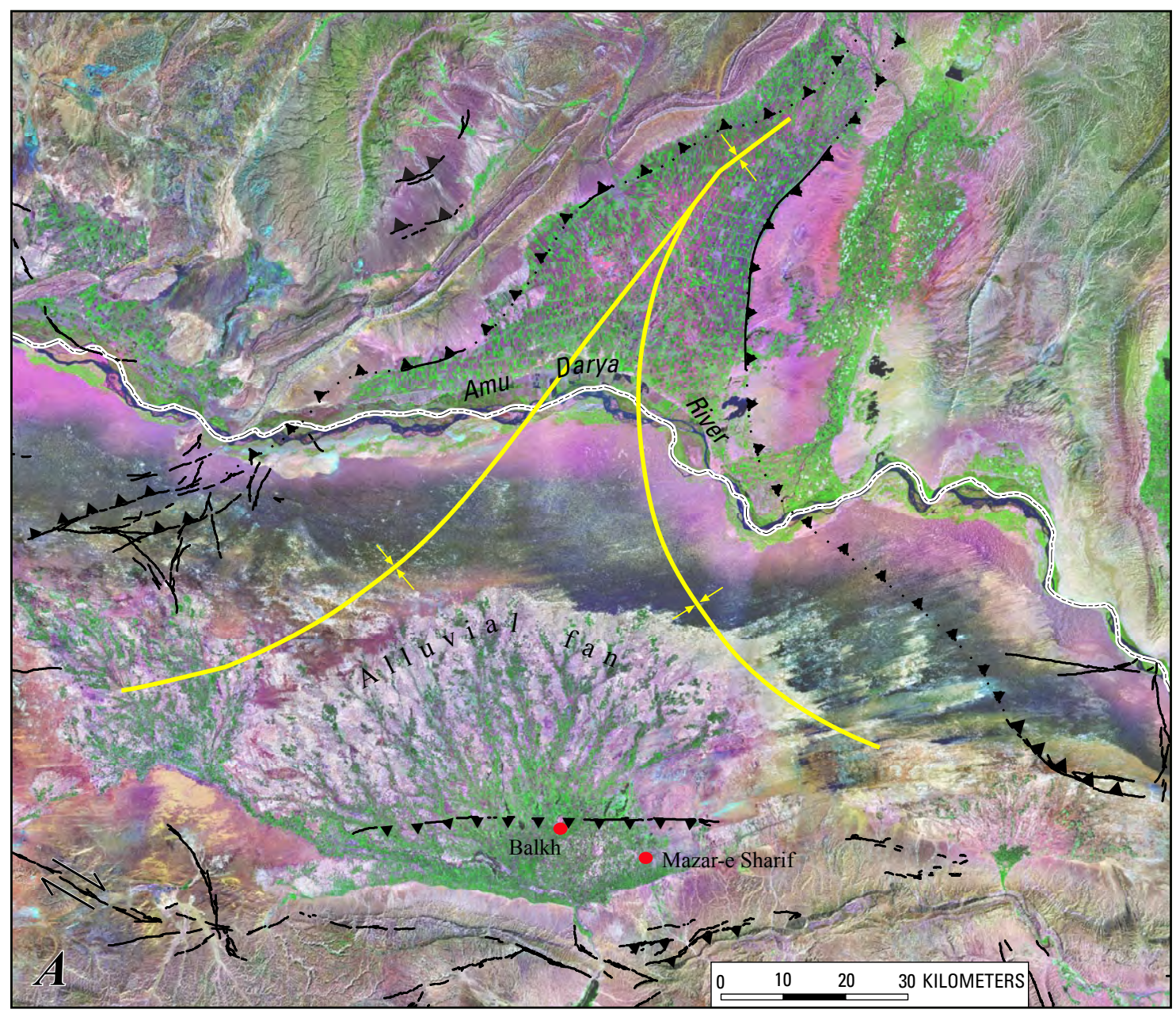

Figure 11 $A$. Probable and possible active features in the area around Mazar-e Sharif, north-central Afghanistan. The large alluvial fan is filling a basin that is located in front of active folds to the south. Yellow lines and arrows show the approximate axis of the syntaxial basin. Features inferred to be thrust faults are shown with teeth on the upthrown side; faults are dotted where concealed. Amu Darya River and white dashed line are the northern border of Afghanistan. Image is a panchromatically enhanced Landsat image that merges bands $7+4+1$. See figure 11 for location.

\section{Domain 6 - The Western Hari Rud Fault System}

Domain 6 spans the region where the right-lateral motion along the central and eastern sections of the Hari Rud fault intersects a region of north-south-trending, right-lateral shear associated with the major fault systems of the Sistan suture zone (fig. 12).

The western section of the Hari Rud fault system (pl. 1, no. 123 and 124) is marked by an abrupt southwestward deflection in the Hari Rud River Valley (fig. 12A). This southwestward deflection may coincide with a compressional left-step in the right-lateral-slip Hari Rud fault system. At this step-over, we mapped a network of features along the prominent range front and on the adjacent alluvial piedmont.
At this compressional step, the topographic relief between the valley and the adjacent range crest exceeds $1.7 \mathrm{~km}$, indicating a substantial amount of long-term uplift that is probably late Cenozoic in age. Our mapped features on the steep Quaternary alluvial fans show evidence of mainly vertical displacement with the youngest alluvium prograding and extending down the fans beyond the features.

At this left-step, we divided the Hari Rud fault system into two sections: 1) a northwestern section that extends through the bedrock range at this step and into a set of basins north of Herat (pl. 1, no. 123), and 2) the western section that continues westward along the range front and defines the northern margin of the Hari Rud River Valley near Herat (pl. 1, no. 124). 


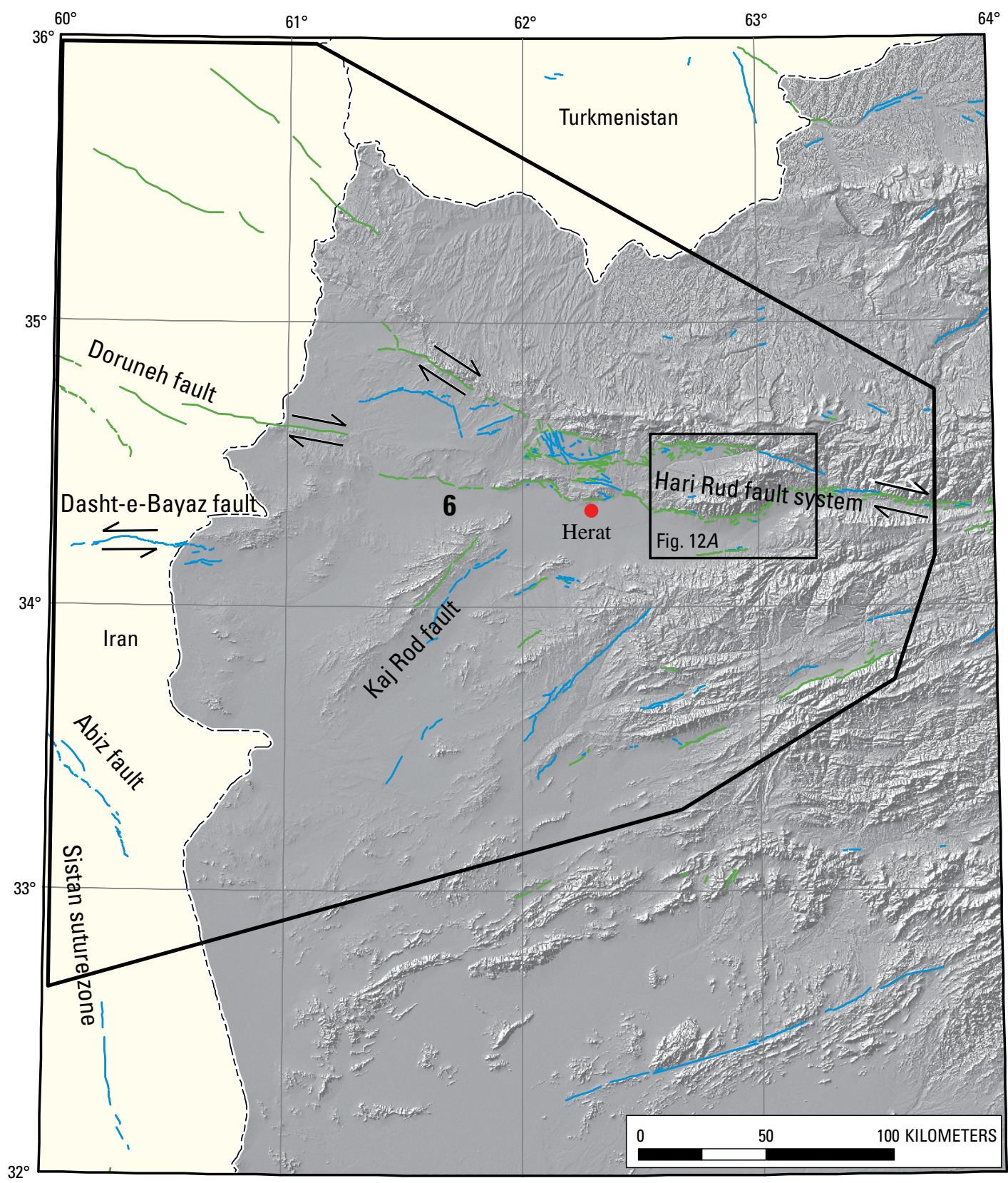

Figure 12. Tectonic domain 6-the Western Hari Rud fault system outlined in black. In this domain, the right-lateral motion on the eastern and central parts of the Hari Rud fault system transitions into a structural style that is more typical of the Basin-and-Range province of the western U.S. East of Herat, the narrow valley of the Hari Rud or Herat River widens at a left-step in the right-lateral fault system. West of this left-step, the valley is bounded by mountains that have steep range fronts and broad alluvial piedmonts. Arrows show directions of movement on lateral-slip faults. Fault categories are category B, green; and category C, blue.

Along the northwestern section, we mapped a network of scattered, somewhat disorganized features that generally bound the northern margin of the basins, but are also present in the basin interiors. The rocks in these basins are mapped as Miocene-late Pleistocene in age, indicating that late Cenozoic and Quaternary deformation has been ongoing in the region. To the west, the range-bounding features may merge with the left-lateral Doruneh fault (fig. 12) and the Jangal thrust system in eastern Iran.

The western section of the fault system defines the northern margin of the Hari Rud River Valley in the vicinity of Herat. Here, we mapped a fairly continuous set of features along the range front and scattered features on the adjacent alluvial piedmont. 


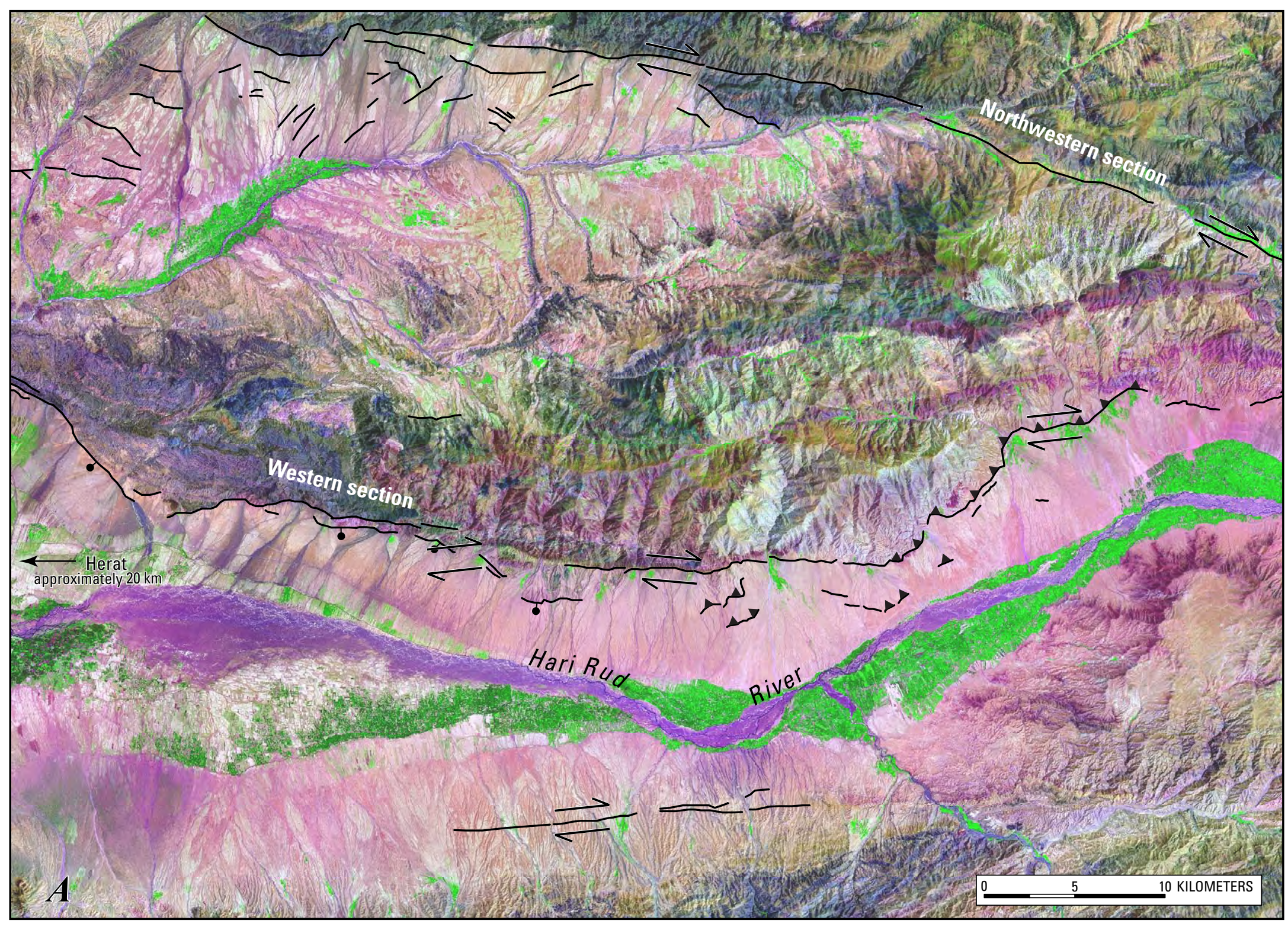

Figure 12A. Map of features along the western part of the Harirud fault system. To the east of this view, the fault system separates into a northwestern section that extends through the bedrock range and into basins north of Herat, and a western section that continues along the northern margin of the Harirud River Valley. Inferred thrust faulting occurs at a left step (to the southwest) in the right-lateral, strike-slip fault system. Black lines are faults, with teeth on the upthrown side of thrust faults; arrows indicate directions of movement on strike-slip faults; bar-and-ball is on downthrown side of normal faults . Image is a panchromatically enhanced Landsat image that merges bands $7+4+1$. See figure 11 for location. 
Westward from the compressional left-step, the terrain west and southwest of Herat has a basin-and-range style of topography that is distinctly different from the narrow, linear strike valleys along the central and eastern parts of the Hari Rud fault system. This obvious difference in regional topography and geomorphology indicates that the area of the western Hari Rud system has been affected by a different style of tectonic deformation, versus the central and eastern regions. The basin-and-range topography indicates that a significant amount of late Cenozoic extension has taken place in this area.

West of Herat, the western section of the Hari Rud fault system (pl. 1, no. 124) appears to terminate near the northern margin of an approximately 50-km-wide basin. Across this basin, we mapped features that step to the north and south, and we mapped scarps along the Doruneh and Dasht-e-Bayaz faults, respectively (fig. 12). Our observations of scarps in this region are consistent with the description of Walker and others (2004), who described about $120 \mathrm{~km}$ of surface rupture on the Dasht-e-Bayaz fault resulting from the two Mw 7.1 earthquakes that occurred in 1968 and 1979.

In the basins south and southwest of Herat, we mapped features along the Kaj Rod fault (pl. 1, no. 125; fig. 12) and along the margins of four other bedrock ranges to the southeast. Each set of features is linear, trends southwest, and is discontinuous to generally continuous. They typically bound a bedrock range or are located on the adjacent alluvial piedmonts. The expression of arcuate, southwest-trending features on alluvial piedmonts along the Kaj Rod fault suggests an oblique-thrust sense of motion. Based on the geometry between the Kaj Rod fault and the right-lateral Hari Rud system, these features would likely accommodate contraction between the right-lateral Hari Rud fault system and the left-lateral Dasht-e-Bayaz fault system to the west.

In the southwestern part of Domain 6 in Iran, we mapped south-southeast-trending, discontinuous, linear features that coincided with part of the Abiz fault, which is a northern extension of the right-lateral Sistan suture zone between Afghanistan and Iran. The Abiz fault right-laterally offsets major rivers and bedrock units, and historical earthquakes (May 10, 1997 Zirkuh-e-Qa'enat Mw 7.2 earthquake) have produced as much as $125 \mathrm{~km}$ of surface rupture (Berberian and others, 1999). In our map area the fault is generally located in strike valleys or where different lithologic units are juxtaposed. We have also identified thrust faults at bends in the fault system. Walker and Jackson (2004) suggest that these fault scarps probably reflect only a minor amount of shortening across the region. The dissection and burial of many scarps clearly shows that much of the faulting in this region is probably pre-Holocene in age.

\section{Domain 7 - Central Afghanistan Accreted Terranes}

Domain 7 encompasses the Helmand block (pl. 1, fig. 1), a mountainous region composed of various terranes that were accreted throughout the Mesozoic and into Cenozoic time. This region is considered to be the most structurally complex part of Afghanistan (Shareq, 1981). This rugged highland is interspersed with valleys and basins, all of which have a general northeast trend (fig. 13). Most valleys are bounded by previously mapped fault systems (Abdullah and Chmyriov, 1977; Treloar and Izatt, 1993). Treloar and Izatt (1993) described northeast-trending, Miocene-Pliocene thrust faults and folds in this domain that created an inverted basin analogous to the Katawaz basin in the Sulaiman fold and thrust belt to the southeast. However, our observations suggest that in the current tectonic regime fault motion is mainly strike-slip, possibly along preexisting thrust faults. Tapponnier and others (1986) suggested that the Helmand block is being actively extruded to the southwest between the left-lateral Chaman and the right-lateral Hari Rud fault systems. This model is consistent with the apparent strikeslip faulting we observe in this region.

Our mapping indicates that probable Quaternary faulting is primarily concentrated on northeast-trending lineaments that coincide with the Helmand (pl. 1, no. 121) and Dorafshan fault (pl. 1, no. 120) systems, and with the Farah Rud fault (pl. 1, no. 126) to the west (fig. 13). We propose that these systems are acting as synthetic, sinistral conjugate shear systems to the major Chaman fault to the east. We mapped other widely distributed possible and probable Quaternary surficial ruptures throughout the domain; these are minor structures that could transfer slip to larger structures.

The Farah Rud fault system coincides with a well-defined strike valley, and left-laterally displaces streams that cross the fault system (fig. 13A). Our observations of Quaternary displacement are consistent with Whitney's (1984) report of Quaternary sinistral displacement on the fault. To the southwest, evidence of Quaternary faulting dissipates in the Helmand basin, where late Pleistocene-Holocene eolian deposits (Whitney, 2006) may be concealing the evidence of faulting.

Along the Darafshan fault zone (pl. 1, no. 120), we mapped discontinuous, sublinear fault scarps in bedrock terrain and along range fronts. The northern limit of this fault zone is marked by a prominent north-trending rectilinear basin that is approximately $25 \mathrm{~km}$ wide and $45 \mathrm{~km}$ long (fig. 13B) (pl. 1, no. 63). We interpret this basin to be a pull-apart basin between the left-lateral Chaman and Darafshan fault systems. In the central part of Domain 7, we mapped features along a linear, 90-km-long, northeasttrending range front that likely corresponds to the main trace 


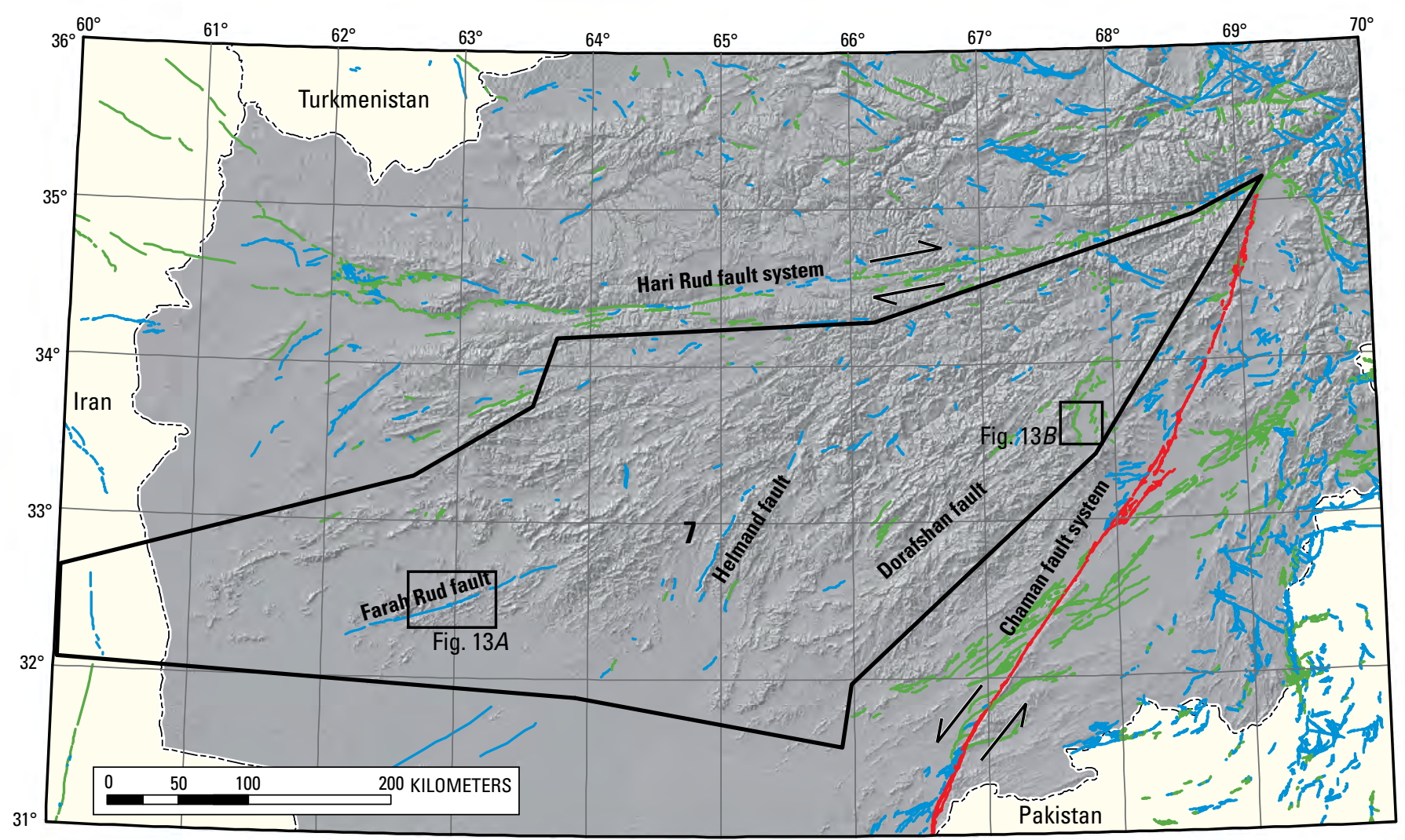

Figure 13. Tectonic domain 7-Central Afghanistan Accreted Terranes and the Helmand-Dorafshan fault system outlined in black. This structurally complex region consists of rugged northeast-trending mountains interspersed with valleys and basins. The region may be actively extruding to the southwest between the left-lateral Chaman fault system to the east and the right-lateral Hari Rud fault system to the north. Arrows indicates directions of movement on fault systems. Fault categories are category A, red; category B, green; and category $\mathrm{C}$, blue.

of the Helmand fault. These features generally coincide with the bedrock-colluvium contact, and locally we observed old piedmont landforms and deposits that are left-laterally displaced. To the northeast, the Helmand fault system steps to the right, is more discontinuous and fragmented, and has little or no evidence of Quaternary activity.

\section{Domain 8 - The Helmand Basin-Makran System}

The Helmand basin in southwestern Afghanistan is located north of accreted terranes associated with the accretionary prism on the north side of the active subduction zone in the Gulf of Oman (Regard and others, 2005). This region has been a closed basin since the Oligocene time (Whitney, 2006). It is bounded to the west by the intensely folded and faulted East Iranian Mountains (fig. 14). Early mapping did not show any faults in the Helmand basin, and those faults that extend southward from Domain 7 abruptly terminate at the basin boundary (Abdullah and Chmyriov, 1977). The lack of historic seismicity in Domain 8 is consistent with the sparse evidence for young surface faulting (fig. 2). In contrast, many long faults in the East Iranian Mountains are part of the active Sistan suture zone (Tirrul and others, 1983; Berberian and others, 1999) and show abundant evidence of activity that spans the Quaternary period. Neogene and Quaternary-aged surficial deposits in the Helmand basin consist of fine- to coarse-grained fluvial and eolian sediments (Whitney, 2006), and large complexes of active sand dunes that could bury and conceal active faults, making it impossible to identify them.

Most of Domain 8 is covered by surficial deposits that have been mapped as being middle Pleistocene or younger in age (Abdullah and Chmyriov, 1977). The low-relief topography in the basin has a subtle but distinct northeasttrending grain, and to the north in Domain 7, this fabric is better defined by bedrock strike ridges, many active stream channels, linear depressions, and bedrock lineaments. In places, aligned volcanic centers (dated as young as $0.6 \pm 0.05$ $\mathrm{Ma}$ ) and long, linear reaches of the fluvial systems give the impression that the general northeast-trending structural grain of Domain 7 to the north may extend into the Helmand basin as suggested by Whitney $(1984,2006)$. Some lineaments in the basin control drainage patterns and Whitney (1984) 


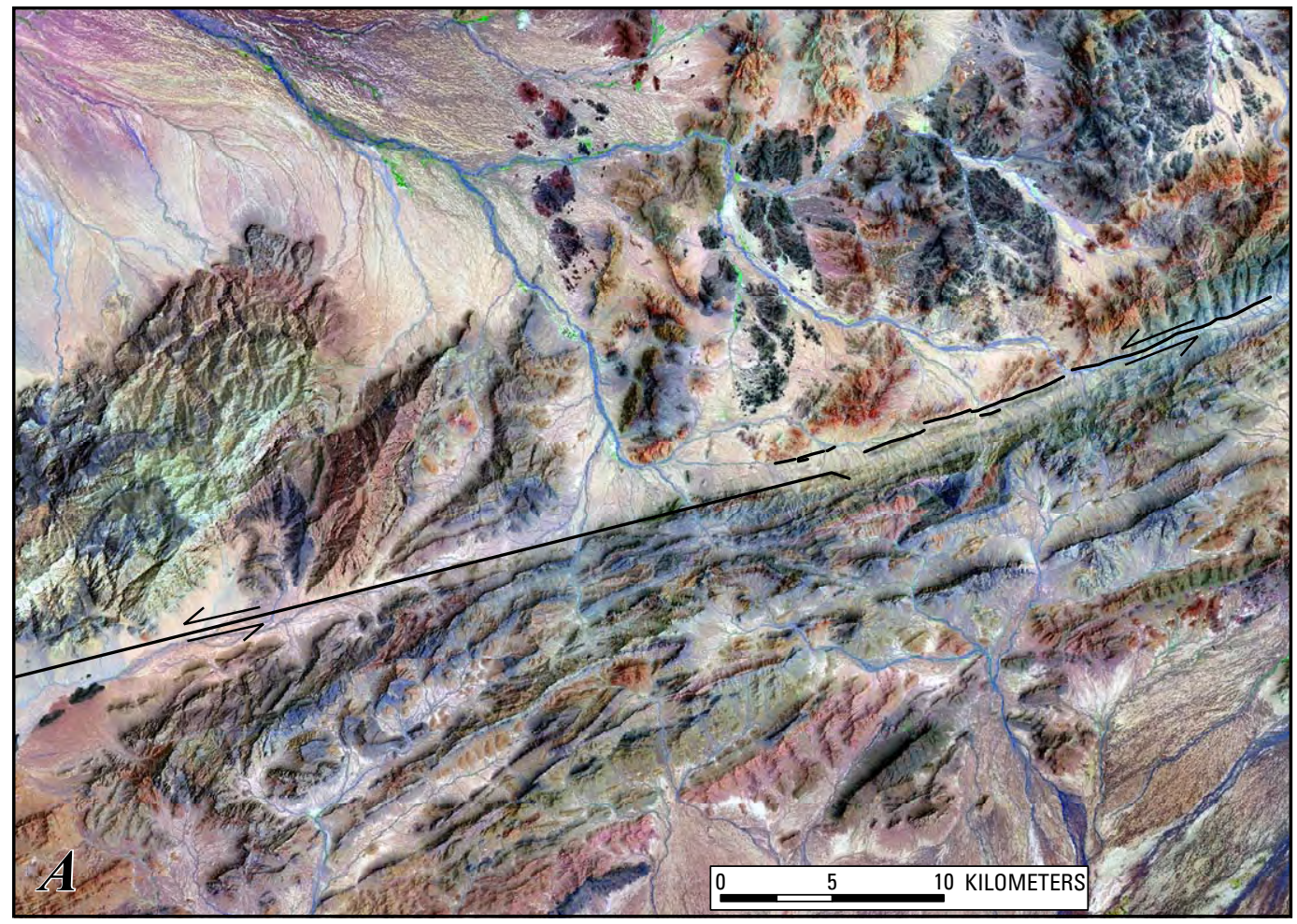

Figure 13A. Image showing the linear strike valley of Farah Rud fault (pl. 1, no. 126), a southeast-trending fault zone that left-laterally offsets drainages that cross the fault system. Faults are black lines with arrows that show directions of movement. Image is a panchromatically enhanced Landsat image that merges bands $7+4+1$. See figure 13 for location.

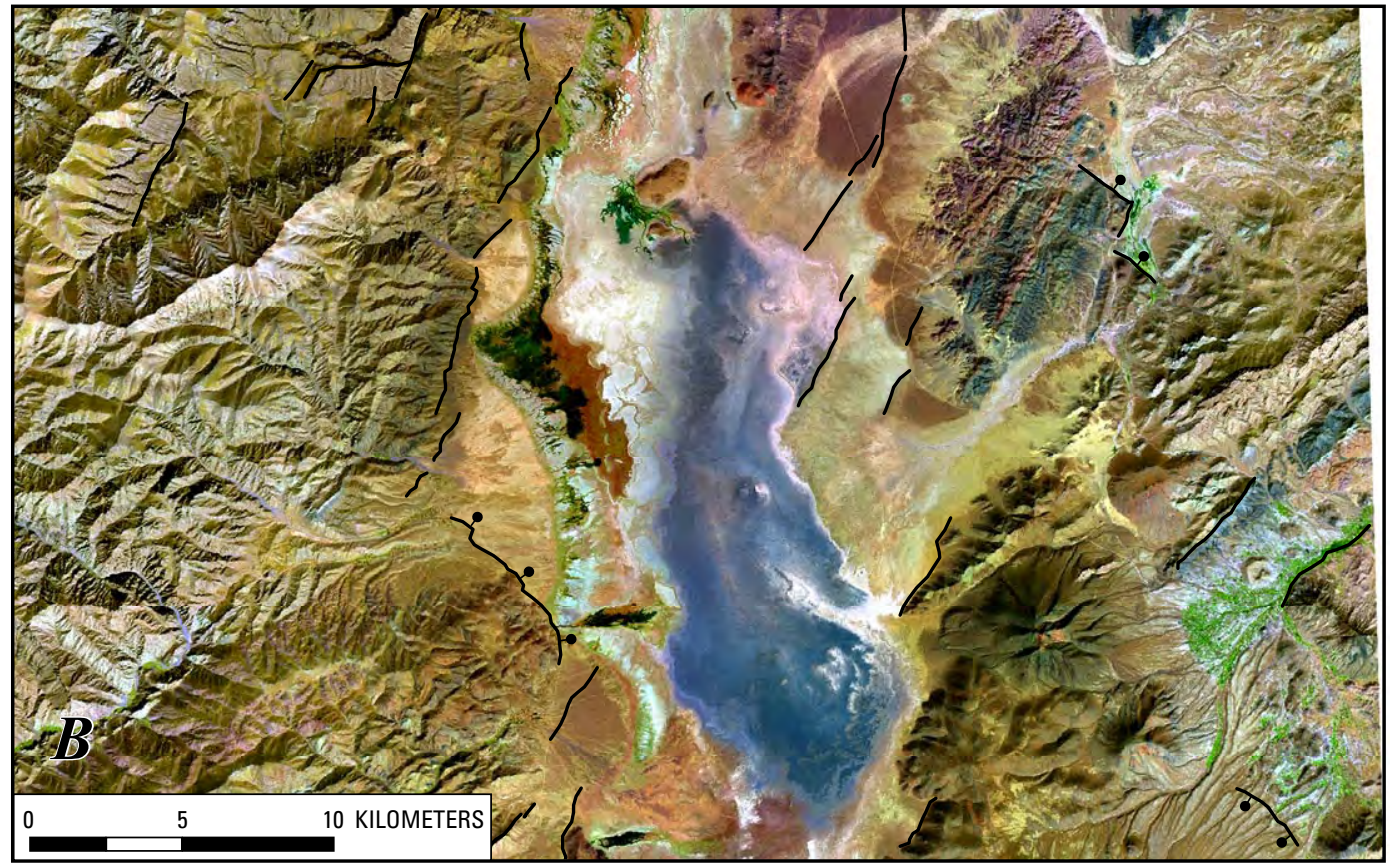

Figure 13B. Image showing pull-apart basin associated with Navar basin system fault (pl. 1, no. 63). This basin is between the northeast-striking, left-lateral Chaman and Dorafshan fault systems. Pull-apart basins commonly form at left steps in left-lateral systems. Faults are black lines; normal faults are shown by a bar-and-ball on the downthrown side. Image is a panchromatically enhanced Landsat image that merges bands $7+4+1$. See figure 13 for location. 


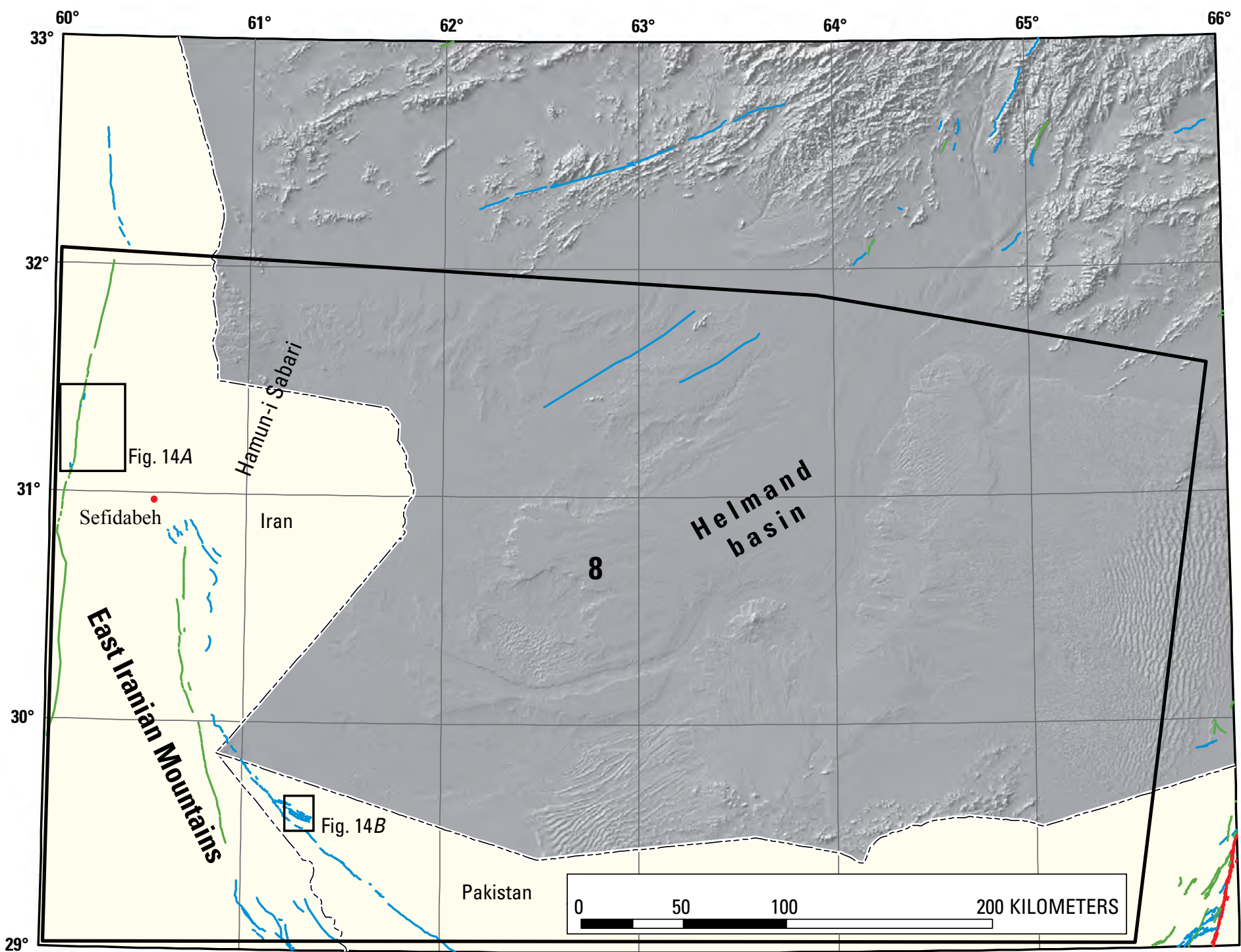

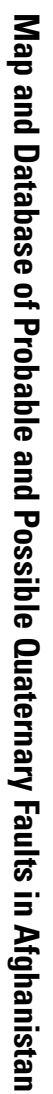

Figure 14. Tectonic domain 8 - Helmand basin-Makran system outlined in black. This domain contains little evidence of active faulting and has very little seismicity in Afghanistan. Active faults and historical earthquakes in eastern Iran are part of the Sistan suture zone. Large areas of domain 8 in Afghanistan are covered by complexes of active sand dunes, which could bury and conceal evidence of active faults. Fault categories are category A, red; category B, green; and category C, blue. 
reported evidence of Quaternary subsidence associated with some features. However, in the north-central part of Domain 8 and the southwestern part of Domain 8, we only found evidence suggesting recurrent Quaternary movement on the Farah Rud fault system.

The Helmand fault (pl. 1, no. 121) is not as well expressed in the basin as it is to the north in Domain 7. Its location is defined by long, linear reaches of the Khash Rud River and adjacent tributaries, and by aligned volcanic centers (basalt cones, Whitney, 1984) southwest of the main range front. Both the Farah Rud and Helmand fault systems may be longer than we show on our map, and could extend southwest to the Iranian border. The general absence of recognizable fault-related landforms in the Helmand basin and the lack of historical seismicity both suggest that deformation rates in this area are substantially less than elsewhere in the country.

In contrast, to the west in the Sistan suture zone which is located in and adjacent to the East Iranian Mountains, faults are geologically prominent features (fig. 14A) (pl. 1, no. 128-135). Although these faults are outside Afghanistan, we include them in our inventory because earthquakes associated with these structures will impact communities and infrastructure in western Afghanistan. In the part of eastern Iran included in this domain, the north- to northwest-trending structural fabric appears to be related to a major zone of dextral-slip faults (Whitney, 1984; Walker and others, 2003, 2004). Collectively, these faults accommodate about 13-16 $\mathrm{mm} / \mathrm{yr}$ of north-south convergence between the Arabian and Eurasian plates (Walker and Jackson, 2004; Allen and others, 2004) on structures that bound the eastern and western edges of the Lut block. A series of north-trending, right-lateral faults that define the eastern edge of the historically aseismic Lut block in eastern Iran are close to Afghanistan (Gansser, 1964; Chandra, 1981). Among these faults, the Zahedan (pl. 1, no. 131 and 132) and East Neh-West Asagie (pl. 1, no. 129) faults are the longest, most continuous faults mapped. Their apparent

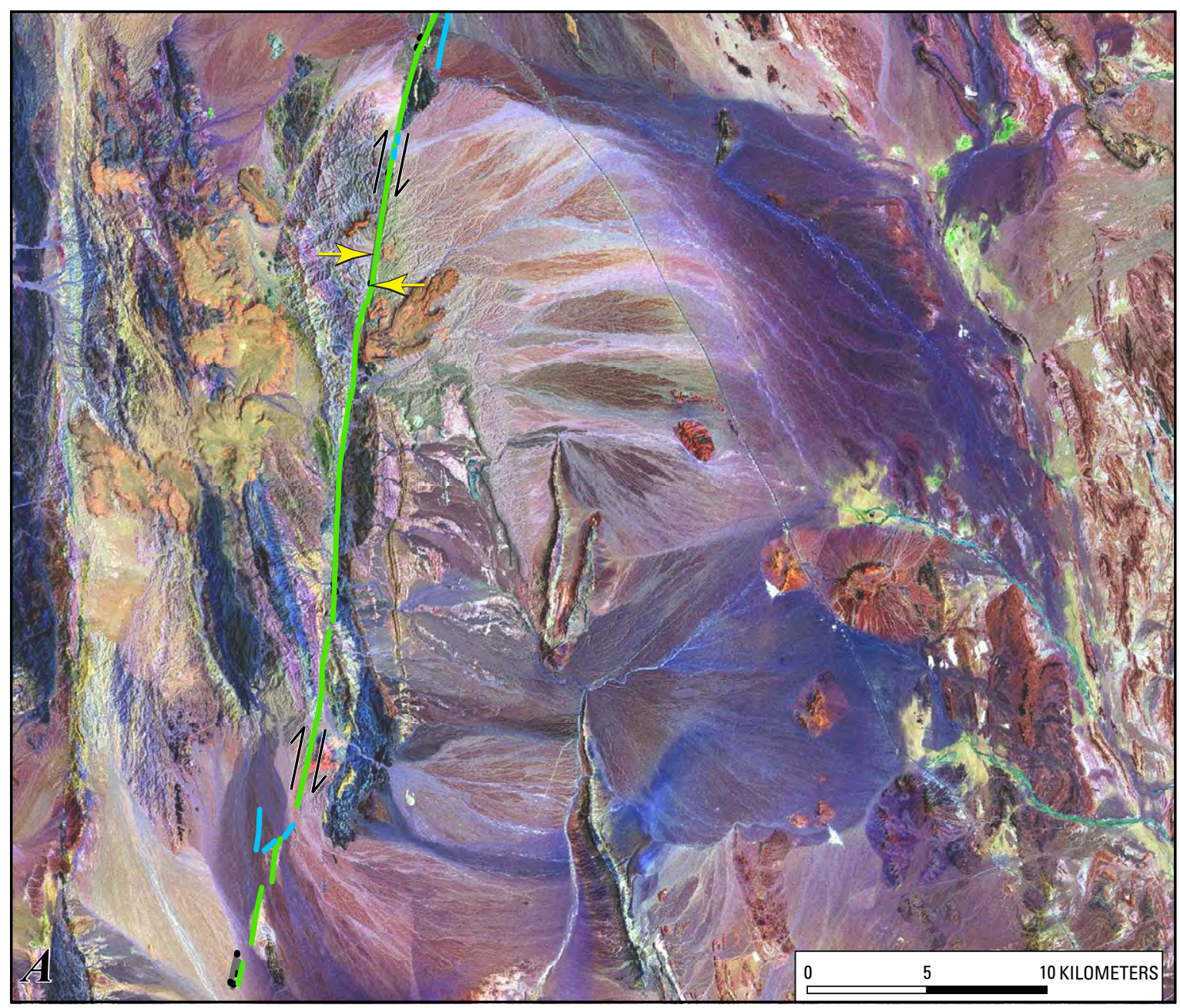

Figure 14A. Landsat image showing evidence of right-lateral movment on East Neh-West Asagie fault (pl. 1, no. 129) of the Sistan suture zone, Iran. Yellow arrows show a major drainage that is right-laterally offset. Black arrows adjacent to faults show directions of movement. Fault categories are category B, green; and category $\mathrm{C}$, blue. Image is a panchromatically enhanced Landsat image that merges bands $7+4+1$. See figure 14 for location. 


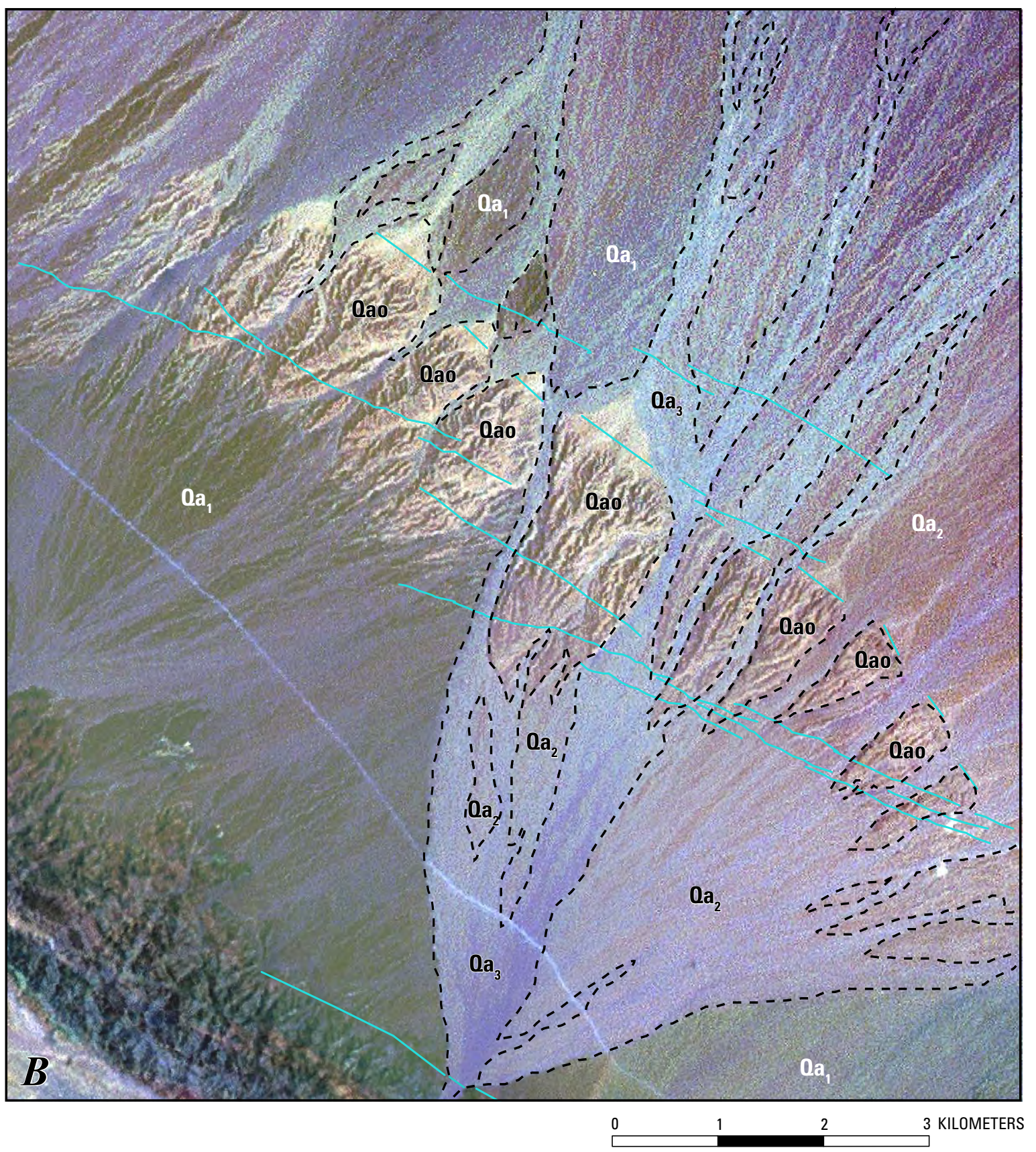

Figure 14B. Surface expression of category $C$ faults shown by blue lines (pl. 1, no. 130 and 132) in the Helmand basin in northwestern Pakistan across the border from southwestern Afghanistan. Surface expression of the fault traces is generally discontinuous. The fault has uplifted an old alluvial fan (Qao) or bedrock(?), and younger alluvium $\left(\mathrm{Qa}_{1}, \mathrm{Qa}_{2}\right.$, and $\left.\mathrm{Qa}_{3}\right)$ has eroded and buried parts of the fault. These relations indicate that there are relatively long time intervals between surface-rupturing earthquakes on this fault. Drainages that cross the fault do not appear to be laterally offset, which indicates that displacement is primarily vertical, probably on thrust faults. Image is a panchromatically enhanced Landsat image that was created by merging bands $7+4+1$. See figure 14 for location. 
sense of movement is right-lateral based on offset bedrock units and streams. Locally, these dextral-slip fault zones are associated with transpressional flower structures at bends and steps in the fault system (Berberian and others, 1999). South of Sefidabeh, Iran, and east of the Zahedan fault, discontinuous late Pleistocene fault scarps record the uplift related to contraction in this area. These scarps are discontinuous on alluvial piedmonts and bound uplifted and incised bench surfaces (fig. 14B). Range-front faults are marked by sublinear, continuous scarps.

Along the western margin of Human-i Sabari (fig. 14), Huntington (1905) reported evidence of Quaternary uplift, and Whitney (1984) measured vertically displaced late Quaternary shorelines that were uplifted as much as $83 \mathrm{~m}$. We note that previously mapped faults terminate at the northern basin margin, which suggests that these fault systems may have been relatively inactive in Quaternary time (Abdullah and Chmyriv, 1977), but field investigations are needed to confirm this inference.

\section{Implications of Probable and Suspect Quaternary Faulting to Regional Tectonics and Kinematics}

Deformed landforms and displaced Quaternary deposits (that is, shutter ridges, stream channels, and alluvium) along the traces of features that we mapped as probable and suspected Quaternary faults, combined with information from previous studies in Afghanistan and the surrounding region, provided us with a regional perspective of the pattern of contemporary deformation (fig. 15). From this pattern, we can infer relations that better characterize the region's kinematics.

In the Hindu Kush and the adjacent ranges in northern Pakistan (Domain 3), we recognized a general pattern of northeast-trending, southeast-verging thrust faults that are cut and linked by a network of northwest-trending strike-slip fault zones. Our interpretation of both active thrust and strike-slip faulting in this region is consistent with the focal mechanisms for historical earthquakes (Verma and others, 1980), which showed roughly equal numbers of thrust and strike-slip mechanisms in the Hindu Kush region. The southeast-verging thrust faulting that dominates deformation southeastward into the Sulaiman fold and thrust belt (Domain 2) is a direct consequence of the Indian-Eurasian plate collision. Many northwest-trending faults show right-lateral movement synthetic to the major Karakoram fault, which is approximately $50 \mathrm{~km}$ east of our map area. Normal and thrust faults are present at right and left stepovers in these strike-slip faults, respectively.

In southeastern Afghanistan (Domain 1), the left-lateral slip on the Chaman fault system is largely confined to the main Chaman fault, but to the north, the slip is transferred to several northeast-trending, synthetic fault systems (for example, the Gardiz and Mokur fault systems), and at the southern margin of the Kabul block, minor thrust faults have developed where north-south shortening encounters Late Proterozoic crystalline basement (Badshah and others, 2000). Our observation that the Kabul block is bounded to the east and west by the right-lateral Sorubi fault and the left-lateral Chaman-Paghman fault system, respectively, is consistent with the distribution of shallow historical seismicity (Prevot and others, 1980), showing both right-lateral and left-lateral focal mechanisms, respectively, for these faults.

The dominant structural grain in northeastern Afghanistan and northward into the Pamir Mountains (Domain 3) consists of a fold-and-thrust belt that is convex to the northnorthwest. However, younger structures have a southeastconvex pattern similar to the Zeravshan Range to the north in Tajikistan and the Sulaiman fold-and-thrust belt to the south. These relations suggest the possibility that the initial contraction caused by the Indian-Eurasian plate collision was accommodated by north-verging thrust faults, but the more recent Quaternary and contemporary deformation is being accommodated by south-southeast-verging thrust faults and transform (strike-slip) systems.

This general pattern of structural relations appears to continue into the North Afghan platform region (Domain 4), where dextral strike-slip fault systems merge with and link southeast-verging thrust faults. Locally, extensional basins have formed at right steps in these dextral shear systems.

In the Tajik basin (Domain 5), we mapped probable and suspected Quaternary fault scarps that apparently define a closing syntaxial basin. North-directed thrust faults associated with the Alburz-Marmul fault are encountering southeastdirected contraction associated with northeast-trending thrust faults in Tajikistan. We identified minor displacement on west-northwest-verging thrust faults along the eastern margin of the basin. The western extent of the dextral Hari Rud fault system shows evidence of minor thrust faulting at bends in the system. Active dextral-oblique thrust faulting in northern Iran is induced by dextral motion along the Sistan suture zone.

In central Afghanistan, sinistral strike-slip faulting on the Farah Rud, Helmand, and Darafshan fault systems (Domain 7) accommodates contraction between the Indian and Eurasian plates as the Helmand block is being slowly extruded to the southwest. Minor faults dispersed throughout the Helmand block apparently act as transfer zones between the three major systems mentioned above. In the Helmand basin in south-central and southwestern Afghanistan (Domain 8), we found limited evidence of Quaternary fault activity, perhaps in part because widespread, active eolian deposits may be concealing evidence of recent activity. The southwestern margin of the Helmand basin coincides with the Sistan suture zone, which is tectonically active as demonstrated by the occurrence of major historical earthquakes and displaced Quaternary features. In southern Afghanistan, both the Chaman fault and Sistan suture zone merge into the structurally complex Makran accretionary prism, which overlies the north-dipping Makran subduction zone.

The kinematic inferences that we have determined from our analysis of satellite imagery and topography provide 


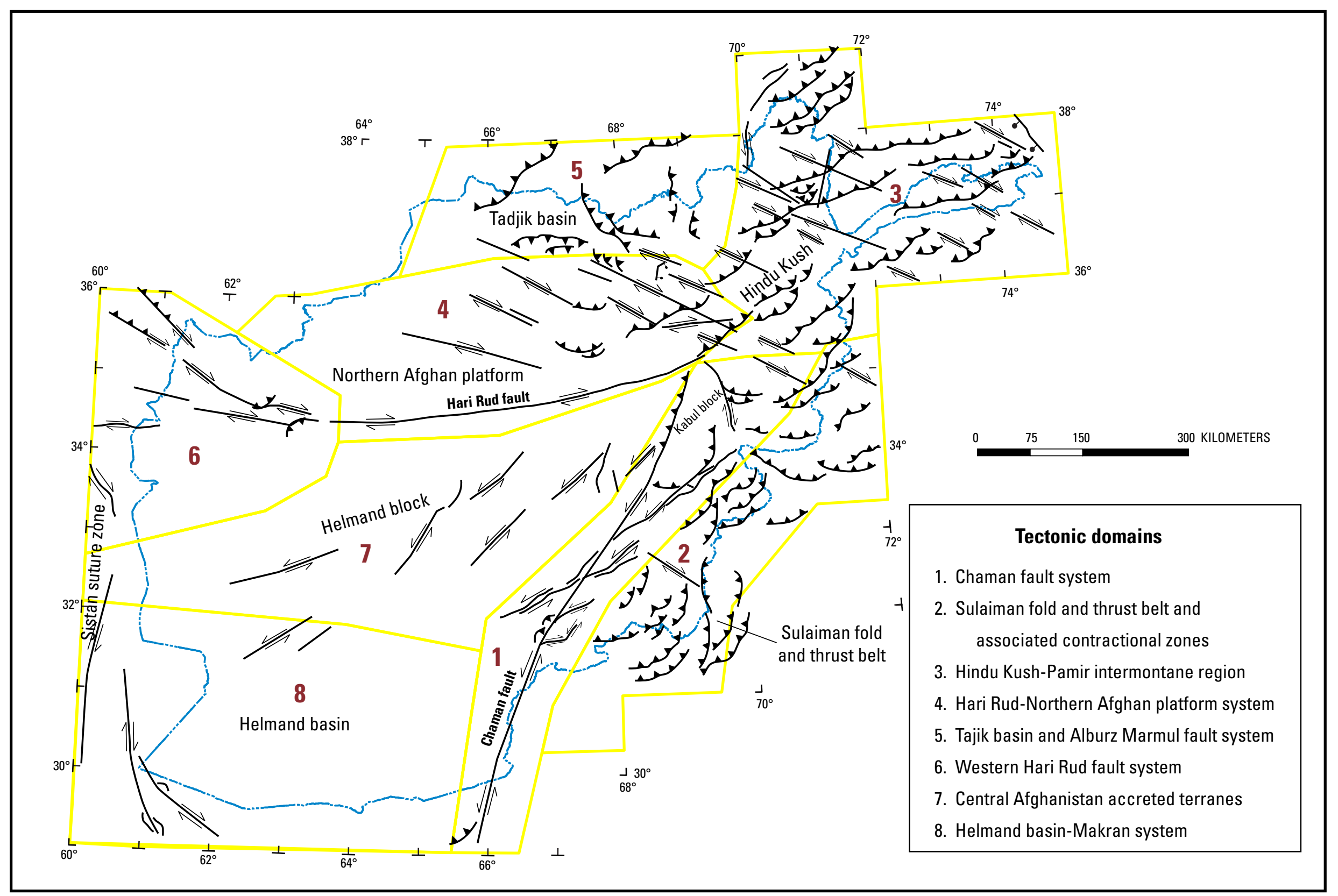

Figure 15. Schematic map of probable and possible Quaternary faults in Afghanistan showing kinematic relations and nationwide patterns of deformation. Each domain is numbered as discussed in text and boundaries are shown in yellow. Solid lines with arrows denote strike-slip faults, arrows show directions of movement. Solid line with teeth denote thrust faults, teeth on upthrown block. Ball-and-bar symbol denotes normal faults with symbol on downthrown block. 
insight into not only the contemporary tectonics in Afghanistan, but also the structural complexity and mechanical variations that can develop in a large orogenic belt. We offer this model of deformation styles as a first step to assist with the identification of active structures by subsequent studies. Our analysis is a starting point to further understanding the nature and distribution of structures in Afghanistan that could potentially generate strong, destructive earthquakes, and therefore pose a significant seismic hazard. To fully characterize these structures and their associated hazards requires numerous, detailed, ground-based studies, but the mapping and observations we present here provide a foundation for such future studies and yield a nationwide perspective on the distribution, qualities, and challenges associated with understanding the hazards posed by active faults in Afghanistan.

\section{Acknowledgments}

This study and report was supported the U.S. Geological Survey's Afghanistan Project, which is funded by the U.S. Agency for International Development (USAID) Mission in Kabul through Interagency Agreement 306-P-00-04-0056600. We thank Robert Bohannon and James Yount for reviews and suggestions that clarified aspects of this report. We also thank Phil Davis (USGS, Flagstaff, Ariz.) for assembling the set of color-balanced Landsat images of Afghanistan that were essential in our study.

\section{References Cited}

Abdullah, S., and Chmyriov, V.M., 1977, Map of mineral resources of Afghanistan: Ministry of Mines and Industries of the Democratic Republic of Afghanistan, Department of Geological and Mineral Survey, scale 1:500,000.

Abers, G., Bryan, C., Roecker, S., and McCaffrey, R., 1988, Thrusting of the Hindu Kush over the southeastern Tadjik basin, Afghanistan-Evidence from two large earthquakes: Tectonics, v. 7, no. 1, p. 41-56.

Alford, D., and Schuster, R., 2000, Introduction and summary, in Alford, D., and Schuster, R., eds., Usoi Landslide Dam and Lake Sarez-An assessment of hazard and risk in the Pamir Mountains, Tajikistan: Geneva, Switzerland, United Nations International Strategy for Disaster Reduction (ISDR) Prevention Series No. 1 (ISBN 92-1-132022-4), p. 1-18.

Allen, M., Jackson, J., and Walker, R., 2004, Late Cenozoic reorganization of the Arabia-Eurasia collision and the comparison of short-term and long-term deformation rates: Tectonics, v. 23, TC2008, 16 p.

Ambraseys, N., and Bilham, R., 2003, Earthquakes in Afghanistan: Seismological Research Letters, v. 74, no. 2, p. 107-123.
Babayev, A.M., 1983, Holocene movements of Al'Burz anticline, north Afghanistan: Byulleten' Moskovskogo Obshchestva Ispytateley Prirody, Otdel Geologicheskiy, v. 58, no. 4, p. 65-72 [in Russian].

Badshah, M.S., Gnos, E., Jan, M.Q., and Afridi, M.I., 2000, Stratigraphic and tectonic evolution of the northwestern Indian plate and Kabul block, in Khan, M.A., Treloar, P.J., Searle, M.P., and Jan, M.Q., eds., Tectonics of the Nanga Parbat Syntaxis and the Western Himalaya: Geological Society of London, Special Publications no. 170, p. 467-475.

Baum, R.L., Crone, A.J., Escobar, D., Harp, E.L., Major, J.J., Martinez, M., Pullinger, C. and Smith, M.E., 2001, Assessment of landslide hazards resulting from the February 13, 2001, El Salvador earthquake: U.S. Geological Survey Open-File Report 01-119, 20 p. [available at: http://pubs. usgs.gov/of/2001/ofr-01-0119/].

Berberian, M., Jackson, J.J., Qorashi, M., Khatib, M.M., Priestly, K., Talebian, M., and Ghafuri-Ashtiani, M., 1999, The 1997 May 10 Zirkuh (Qa'enat) earthquake ( $M_{w}$ 7.2) Faulting along the Sistan suture zone of eastern Iran: Geophysical Journal International, v. 136., no. 3, p. 671-694.

Bernard, M., Shen-Tu, B., Holt, W.E., and Davis, D.M., 2000, Kinematics of active deformation in the Sulaiman Lobe and Range, Pakistan: Journal of Geophysical Research, v. 105, no. B6, p. 13253-13279.

Bird, P., 2003, An updated digital model of plate boundaries: $\mathrm{G}^{3}$, Geochemistry, Geophysics, and Geosystems, v. 4, no. 3, p. 1-52.

Brown, E.T., Bendick, R., Bourles, D.L., Gaur, V., Molnar, P., Raisbeck, G.M., and Yiou, F., 2002, Slip rates of the Karakorum fault, Ladakh, India, determined using cosmic ray exposure dating of debris flows and moraines: Journal of Geophysical Research, v. 107, no. B9, p. 2192, doi:10.1029/ 2000JB000100.

Chandra, U., 1978, Seismicity, earthquake mechanisms and tectonics along the Himalayan mountain range and vicinity: Physics of the Earth Planet Interiors, v. 16, p. 109-131.

Chandra, U., 1981, Focal mechanism solutions and their tectonic implications for the eastern Alpine-Himalayan region, in Gupta, H.K., and Delany, F.M., eds., Zagros-Hindu KushHimalaya geodynamic evolution: American Geophysical Union and Geological Society of America, Geodynamics Series, v. 3, p. 243-271.

Chirico, P.G., and Barrios, B., 2005, Void filled SRTM digital elevation model of Afghanistan: U.S. Geological Survey Data Series 130, 1 disc.

Davis, P.A., 2006, Calibrated Landsat ETM+ Nonthermalband image mosaics of Afghanistan: U.S. Geological Survey Open-File Report, OFR 2006-1345, 16 p. [available at: http://pubs.usgs.gov/of/2006/1345/]. 
Dewey, J.W. (ed.), 2006, Seismicity of Afghanistan and vicinity: U.S. Geological Survey Open File Report 2006-1185, 18 p. [available at: http://pubs.usgs.gov/of/2006/1185/].

Doebrich, J.L., and Wahl, R.R., 2006, Geologic and mineral resource map of Afghanistan: U.S. Geological Survey Open-File Report 2006-1038, 1 pl. [available at: http:// pubs.usgs.gov/of/2006/1038/].

Gansser, A., 1964, Geology of the Himalayas: London-New York-Sydney, Interscience Publications, John Wiley \& Sons, 289 p.

Harp, E.L., and Crone, A.J., 2006, Landslides triggered by the October 8, 2005, Pakistan earthquake and associated landslide-dammed reserviors: U.S. Geological Survey Open-File Report 2006-1052, 10 p. [available at: http://pubs.usgs. gov/of/2006/1052/].

Huntington, Ellsworth, 1905, The basin of eastern Persia and Sistan, in Pumpelly, Raphael, ed., Explorations in Turkestan: Washington, D.C., Carnegie Institution, v. 26, p. 219-316.

Jade, Sridevi, 2004, Estimates of plate velocity and crustal deformation in the Indian subcontinent using GPS geodesy: Current Science, v. 86, no. 10, p. 1443-1448.

Lawrence, R.D., Khan, S.H., and Nakata, T. 1992, Chaman fault, Pakistan-Afghanistan, in Bucknam, R.C., and Hancock, P.L., eds., Major active faults of the worldResults of IGCP project 206: Annnales Tectonicae, Supplement to v. 6, p. 196-223.

Leith, W., and Alvarez, W., 1985, Structure of the Vakhsh fold-and-thrust belt-Tadjik SSR geologic mapping on a Landsat image base: Geological Society of America Bulletin, v. 96, p. 875-885.

McDougall, J.W., and Hussain, A., 1991, Fold and thrust propagation in the western Himalaya based on a balanced cross section of the Surghar Range and Kohat Plateau, Pakistan: American Association of Petroleum Geologists Bulletin, v. 75 , no. 3 , p. $463-478$.

Nakata, T., Tsutsumi, H., Khan, S.H., and Lawrence, R.D., 1991, Active faults of Pakistan: Hiroshima, Hiroshima University, Japan, Research Center for Regional Geography Special Publication no. 21, 141 p.

Prevot, R., Hatzfield, D., Roecker, S.W., and Molnar, P., 1980, Shallow earthquakes and active tectonics in eastern Afghanistan: Journal of Geophysical Research, v. 85, no. B3, p. 1347-1357.

Regard, V., Bellier, O., Thomas, J.C., Bourles, D., Bonnet, S., Abbassi, M.R., Braucher, R., Mercier, J., Shabanian, E., Soleymani, Sh., Feghhi, Kh., 2005, Cumulative right-lateral fault slip rate across the Zagros-Makran transfer zoneRole of the Minab-Zendan fault system in accommodating Arabia-Eurasia convergence in southeastern Iran: Geophysics Journal International, v. 162, p. 177-203.
Ruleman, C.A., 2005, Annotated bibliography for Quaternary faulting and geomorphic/tectono-morphic development of Afghanistan-Progress Report for Afghan Geologic Hazards Activities: U.S. Geological Survey Internal Report, 12 p.

Sella, G.F., Dixon, T.H., Mao, A., 2002, REVEL-A model for recent plate velocities from space geodesy: Journal of Geophysical Research, v. 107, 1 pl. doi:10.1029/ 2000JB000033.

Shareq, Abdullah, 1981, Geological and geophysical investigations carried out in Afghanistan over the period 19721979, in Gupta, H,K, and Delany, F.M., eds., Zagros, Hindu Kush, Himalaya-Geodynamic evolution: American Geophysical Union Geodynamics Series 3, p. 7586, 1 pl., scale $1: 2,500,000$.

Tapponnier, P., Matauer, M., Proust, R., and Cassaigneau, F., 1981, Mesozoic ophiolites, sutures, and large-scale tectonic movements in Afghanistan: Earth and Planetary Science Letters: v. 52, p. 355-371.

Tapponnier, P., Molnar, P., Proust, F., and Bousquet, J.C., 1976, Quelques observations microtectoniques et sismotectoniques sur les mouvements recente et actuels de grands decrochements en Afghanistan: Réunales Annuales Sciences Terre, p. 373 [in French].

Tapponnier, P., Peltzer, G., and Armijo, R., 1986, On the mechanics of the collision between India and Asia, in Coward, M.P., and Ries, A.C., eds., Collision Tectonics: Geological Society Special Publications no. 19, London, Geological Society of London, p. 115-157.

Tirrul, R., Bell, I.R., Griffis, R.J., and Camp, V.E., 1983, The Sistan suture zone of eastern Iran: Geological Society of America Bulletin, v. 94, p. 134-150.

Treloar, P.J., and Izatt C.N., 1993, Tectonics of the Himalayan collision between the Indian Plate and the Afghan Block: a synthesis, in Treloar, P.J., and Searle, M.P., eds., Himalayan

Tectonics: Geological Society Special Publication no. 74, London, Geological Society of London, p. 69-87.

Verma, R.K., Mukhopadhyay, M., and Bhanja, A.K., 1980, Seismotectonics of the Hindukush and Baluchistan arc: Tectonophysics, v. 66, p. 301-322.

Vernant, P., Nilforoushan, F., Masson, F., Hatzfeld, D., Abbassi, M., Vigny, C., Tavakoli, F., Bayer, R., Martinod, J., Ashtiani, M., Chery, J., 2004, Contemporary crustal deformation and plate kinematics in the Middle East constrained by GPS measurements in Iran and north Oman: Geophysical Journal International, v. 157, p. 381-398.

Walker, R., and Jackson, J., 2004, Active tectonics and late Cenozoic strain distribution in central and eastern Iran: Tectonics, v. 23, TC5010, 24 p. 
Walker, R., Jackson, J., and Baker, C., 2003, Surface expression of thrust faulting in eastern Iran-Source parameters and surface deformation of the 1978 Tabas and 1968 Ferdows earthquake sequences: Geophysical Journal International, v. 152, p. 749-765.

Walker, R., Jackson, J., and Baker, C., 2004, Active faulting and seismicity of the Dasht-e-Bayaz region, eastern Iran: Geophysical Journal International, v. 157, p. 265-282.

Wellman, H.W., 1965, Active wrench faults of Iran, Afghanistan and Pakistan, Geologische Rundschauw, v. 55, p. 716-735.

Wheeler, R.L., Bufe, C.G., Johnson, M.L., and Dart, R.L., 2005, Seismotectonic map of Afghanistan with annotated bibliography: U.S. Geological Survey Open-File Report 2005-1264, 31p. [available at: http://pubs.usgs.gov/ of/2005/1264/].
Whitney, J.W., 1984, The geology and geomorphology of the Helmand basin, Afghanistan: Baltimore, Johns Hopkins University, Ph.D. dissertation, 221 p.

Whitney, J.W., 2006, Geology, water and wind in the lower Helmand basin, southern Afghanistan: U.S. Geological Survey Scientific Investigations Report 2006-5182, 40 p. [available at: http://pubs.usgs.gov/of/2006/1345/].

Yeats, R.S., and Hussain, S.M., 1989, Zone of late Quaternary deformation in the southern Peshawar Basin, Pakistan, in Malinconico, L.L., and Lillie, R.J., eds., Tectonics of the Western Himalaya: Geological Society of America Special Paper 232, p. 265-274.

Yeats, R.S., and Madden, C., 2003, Damage from the Nahrin, Afghanistan, earthquake of 25 March 2002: Seismological Research Letters, v. 74, no. 3, p. 305-311. 